


\section{Geohydrologic Summary of the Pearl River Basin,}

Mississippi and Louisiana

By JOSEPH W. LANG

CONTRIBUTIONS TO THE HYDROLOGY OF THE UNITED STATES

GEOLOGICAL SURVEY WATER-SUPPLY PAPER 1899-M

Prepared in cooperation with the

U.S. Army Corps of Engineers, Mobile District

Describes the geologic and hydrologic framework and its relationship to availability, quantity, and quality of water in a major river basin of the Gulf Coast region

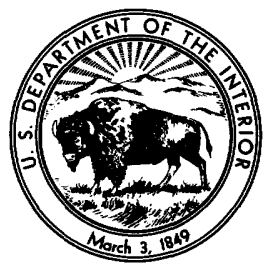

\begin{tabular}{|c|}
\hline U. S. E. S. \\
WATER RESOURCES DIVISION \\
ROLLA. MO. \\
R E C E I V E \\
APR 131972 \\
AM \\
$7,8,9,10,11,12,1,2,3,4,5,6$ \\
\hline
\end{tabular}




\section{UNITED STATES DEPARTMENT OF THE INTERIOR ROGERS G. B. MORTON, Secretary}

\section{GEOLOGICAL SURVEY}

V. E. McKelvey, Director

Library of Congress catalog-card No. 78-185311

For sale by the Superintendent of Documents, U.S. Government Printing Office Washington, D.C. 20402 - Price $\$ 1$ (paper cover)

Stock Number 2401-2027 


\section{CONTENTS}

\begin{tabular}{|c|c|}
\hline & Page \\
\hline Abstract.2. & M1 \\
\hline Summary of water availability & 2 \\
\hline urpose and scope of this report & 6 \\
\hline he river basin & 7 \\
\hline Lccation and development & 7 \\
\hline Landforms and drainage..... & 9 \\
\hline Precipitation and runoff ..... & 11 \\
\hline Geologic framework & 13 \\
\hline Water resources of the basin & 18 \\
\hline and use of the aquifers. & 20 \\
\hline Relationship of ground water to streamflow & 22 \\
\hline Aquifer and well characteristics & 23 \\
\hline Quality of the water. & 29 \\
\hline Saline water as a resource & 35 \\
\hline management and planning considerations_...... & 36 \\
\hline notated bibliography . . . . . . & 38 \\
\hline
\end{tabular}

\section{L L U S T R A T I O N S}

Plate 1. Geohydrologic sections, Pearl River basin, Mississippi and Louisiana. . . . . . .

2. Map showing effect of geology on minimum streamflow and water quality, Pearl River basin, Mississippi and Louisiana. . . . . In pocket

Figures 1-8. Maps showing:

1. Physiographic subdivisions, major drainage, and locations of streamflow gaging stations.........

2. Average annual precipitation and runoff ..........

3. Outcrop pattern and configuration of the base of the Moodys Branch Formation or equivalent and significant structural uplifts....................

4. Outcrop pattern, configuration of the base, and extent of the fresh-water part of the Sparta Sand

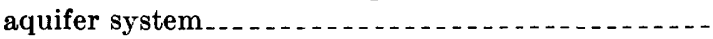

5. Outcrop pattern, configuration of the base, and extent of the fresh-water part of the Meridian-upper Wilcox aquifer system .......................

6. Configuration of the base of fresh ground water....

7. Median dissolved solids at selected streamflow gaging sites, 1962-66.

8. Locations of aquifer-test and ground-watersampling sites . . . . . . . . . . . . . . . . . . .

9. Graph showing theoretical drawdown curves for the Sparta Sand and the Cockfield Formation........... 


\section{T A B L E S}

Page

TABLE 1. Summary of ground-water conditions and geohydrologic relationships that influence the water resources....... In pocket

2. Aquifer and well characteristics ..................... M26

3. Chemical analyses of water from selected wells......... $3 C$

4. Minimum, median, and maximum values for chemical constituents and physical properties of ground water in the Jackson area, central part of the basin . . . . . ......... 


\title{
GEOHYDROLOGIC SUMMARY OF THE PEARL RIVER BASIN, MISSISSIPPI AND LOUISIANA
}

\author{
By Joseph W. LaNG
}

\begin{abstract}
Fresh water in abundance is contained in large artesian reservoirs in sand and gravel deposits of Tertiary and Quaternary ages in the Pearl River basin, a watershed of 8,760 square miles. Shallow, water-table reservoirs occur in Quaternary deposits (Pleistocene and Holocene) that blanket most of the uplands in the southern half of the basin and that are present in smaller upland areas and along streams elsewhere. The shallow reservoirs contribute substantially to dryweather flow of the Strong River and Bogue Chitto and of Holiday, Lower Little, Silver, and Whitesand Creeks, among others. About 3 billion acre-feet of ground water is in storage in the fresh-water section, which extends from the surface to depths ranging from about sea level in the extreme northern part of the basin to more than 3,000 feet below sea level in the southern part of the basin.

Variations in low flow for different parts of the river basin are closely related to geologic terrane and occurrence of ground water. The upland terrace belt that crosses the south-central part of the basin is underlain by permeable sand and gravel deposits and yields more than 0.20 cubic feet per second per square mile of drainage area to streamflow, whereas the northern part of the basin, underlain by clay, marl, and flne to medium sand, yields less than 0.05 cubic feet per second per square mile of drainage area (based on 7-day $Q_{2}$ minimum flow computed from records). Overall, the potential surface-water supplies are large.

Because water is available at shallow depths, most of the deeper aquifers have not been developed anywhere in the basin. At many places in the south, seven or more aquifers could be developed either by tapping one sand in each well or by screening two or more sands in a single well. Well flelds each capable of producing several million gallons of water a day are feasible nearly anywhere in the Pearl River basin.

Water in nearly all the aquifers is of good to excellent quality and requires little or no treatment for most uses. The water is a soft, sodium bicarbonate type and therefore has a low to moderate dissolved-solids content. Mineral content increases generally downdip in an aquifer. Excessive iron, common in shallow aquifers, is objectionable for some water uses. Water from the streams, except
\end{abstract}


in salty tidal reaches, is less mineralized than ground water; at 10 sites the median dissolved-solids content in streamflow was 50 milligrams per liter or less.

Moderately intensive ground-water development has been made in the Bogalusa area, Louisiana; at the Mississippi Test Facility, Hancock County, Miss.; and in the Jackson area, Mississippi. Wells with pumping rates of $\mathbf{5 0 0}$ to 1,000 gallons per minute each are common throughout the Pearl River basin, and some deep wells flow more than 3,000 gallons per minute in the coastal lowland areas. Probably 20 million gallons per day of artesian water flows uncontrolled from wells in the southern part of the basin. Ground-water levels, except in the higher altitudes, are within 60 feet of the surface, and flowing wells are common in the valleys and in the coastal Pine Meadows. Decline of water level is a problem in only a few small areas.

Saline water as a resource is available for development from aquifers and streams near the coast and from aquifers at considerable depth in most of the Pearl River basin. Pollution is a problem in oil fields and in reaches of some streams below sewage and other waste-disposal points. The basin estuary contains water of variable quality but has potential for certain water-use developments that will require special planning and management.

\section{SUMMARY OF WATER AVAILABILITY}

The Pearl River basin cuts across the heart of the central Gulf Coastal Plain, which has more potential for ground-water development than any other region of comparable size in the nation. Surfacewater potential also is large. In the basin, six or more giant ground-water storage and distribution systems are available for future development and management. These systems, which extend beyond the topographic boundary of the Pearl basin, can be subdivided into several large units containing one or more aquifers. A water-table aquifer and at least one artesian aquifer are present in almost every unit, and in the southern part of the basin as many as 10 aquifers occur at some places.

The magnitude of the ground-water reserve is indicated by the fairly large dry-weather streamflow, a high percentage of which is overflow from the various aquifers. Based on available information, the 90-percent duration flow of the Pearl River and the West Pearl River at the U.S. Highway 11 crossing between Slidell, La., and Picayune, Miss., is estimated at about 2,500 cfs (cubic feet per second). Minimum flow of $1,550 \mathrm{cfs}$ was recorded here in late 1963 , a very dry year. Additional data are needed before occurrence and rate of flow, including the various parameters that influence the flow, can be more closely defined.

Much of the dry-weather streamflow is from the lowland alluvium and the sandy terrace deposits blanketing the upland hills and ridges between Monticello, Miss., and the mouth of Bogue Chitto. A part of 
the streamflow also is from outcrop areas of water-table aquifers that become artesian downdip. These overflowing aquifers range in age from Quaternary (Pleistocene and Holocene) in the central and southern parts of the basin to Eocene in the northern part, where eroded valleys expose parts of the aquifers. In places, individual wells in these deposits are capable of pumping rates of more than $1,000 \mathrm{gpm}$ (gallons per minute).

A considerable amount of ground water, possibly $20 \mathrm{mgd}$ (million gallons per day) or more, is being wasted by uncontrolled flowing wells in the river basin. This water loss, in turn, contributes to waterlevel decline in the aquifers tapped. Many unused or abandoned flowing wells have been plugged by NASA (National Aeronautics and Space Administration) in their Mississippi Test Facility area.

The water stored in nearly all the many ground-water reservoirs (aquifers) is of good to excellent quality and usually requires little treatment. The chemical quality differs from place to place in individual reservoirs and from reservoir to reservoir, but at a given site the quality in each reservoir is virtually constant. One objectionable feature of the water, for some uses, is its excessive iron content, commonly more than $0.3 \mathrm{mg} / \mathrm{l}$ (milligrams per liter) ${ }^{1}$ in many of the aquifers. Water from the streams, except in tidal reaches near the coast, is less mineralized than ground water; median dissolved-solids content of streams was $50 \mathrm{mg} / \mathrm{l}$ or less at 10 sampling sites in the Pearl River basin.

Principal conclusions reached in the investigation are

1. The total average annual water supply from rainfall in the Pearl River basin is about 26 million acre-feet. Of this total, a large percentage is lost consumptively through evapotranspiration, a small part infiltrates to the ground-water reservoirs, and the remainder becomes streamflow. The average annual runoff (both ground water and streamflow) represents the normal recoverable water supply, which totals about 8 bgd (billion gallons per day), or approximately 9 million acre-feet per year.

2. An aggregate water supply of 1 to $2 \mathrm{bgd}$, suitable in quality for most municipal and industrial needs and irrigation, can be sustained without surface storage in the basin from the latitude of northern Marion County, Miss., to the mouth of Pearl River. This supply includes the dry-weather flow and the estimated potential yield of all the ground-water reservoirs. In addition, large volumes of slightly to moderately saline water $(1,000$ to

1 One milligram per liter is equivalent to 1 part per million by weight. 
$10,000 \mathrm{mg} / 1$ dissolved solids) are available in several aquifers and streams in the coastal lowlands.

3. Water-table aquifers in Quaternary alluvium and upland terrace deposits can provide at least $1 \mathrm{mgd}$ of cool (less than $21^{\circ} \mathrm{C}$, or $70^{\circ}$ F) water at many sites in the southern part of the basin. Many artesian aquifers (several untapped) of early Quaternary, Pliocene, and Miocene ages offer excellent sources of warmer, soft (0-40 mg/l hardness) water. At most sites in Louisiana and adjacent areas in Mississippi, seven or more aquifers could be developed individually or multiply, by drilling multiple-screened wells, to make well fields capable of producing at least 15 to 20 mgd.

4. At the NASA Mississippi Test Facility, Hancock County, and in the adjacent Slidell and Bogalusa areas of Louisiana, individual aquifers are as much as 450 feet thick and average about 100 feet thick. Some of the deep wells that flow more than $3,000 \mathrm{gpm}$ and produce as much as $5,000 \mathrm{gpm}$ by pumping are developed in these aquifers. The usual withdrawal rate for most of the individual industrial wells is 1,000 to $1,500 \mathrm{gpm}$. From the NASA complex to Bogalusa, La., all sands from the surface to a depth of about 3,000 feet below sea level contain fresh water; from Bogalusa northward, the base of fresh water rises until it is about 1,000 feet below sea level in the Monticello, Miss., area.

5. In the central part of the basin, Jackson area to Marion County, Miss., conditions are less favorable than in the southern part for comparably large ground-water developments. Large reserves of good to excellent water are indicated by electric logs of oil tests, but they remain to be developed in most areas. In the Jackson area, five aquifers are available at different places and depths for development of moderate to large water supplies; total withdrawals from two major aquifers (Cockfield Formation and Sparta Sand) are estimated at $15 \mathrm{mgd}$. The deeper, largely undeveloped Meridian-upper Wilcox aquifer system is a major potential water source from Jackson northward.

In the northern part, the Eocene system of aquifers contains fresh-water sections 100 to more than 1,200 feet thick. Wells produce 200 to more than 1,000 gpms each; in some places the aquifer is capable of furnishing $2,000 \mathrm{gpm}$ or more to individual wells. Some sources are practically untapped. Color and iron content may cause problems locally in both the central and the northern areas of the basin. 
6. Water of suitable quality for most uses is available from the Pearl River upstream from Lock 1 in amounts up to the minimum flow; at Bogalusa and Monticello this is 1,020 cfs and $270 \mathrm{cfs}$, respectively (660 mgd and $170 \mathrm{mgd}$ ). During periods of higher flow, correspondingly larger amounts can be withdrawn. Jackson obtains its supply from the river; the flow is controlled by a reservoir northeast of the city. The estuary is a potential water-supply source for some coastal areas.

7. Tides affect the rate of flow in the river channels south of U.S. Highway 11 (between Picayunne, Miss., and Slidell, La.). Salt water moves up the West Pearl channel as far as U.S. Highway 90 (about 6 miles from the river mouth). Occasional hurricane storms and high tides force salt water north of Highway 90, particularly in the East Pearl and in local smaller channels, but rapid flushing usually occurs. The storm and high-tide conditions may cause an increase in salinity in shallow coastal aquifers, and they may cause excessive salinity in the surface waters in poorly drained places for varying periods of time.

8. A close relationship with respect to base-flow yields exists between the geologic and hydrologic features of the river basin. The largest minimum 7-day $Q_{2}{ }^{2}$ streamflow (greater than 0.20 cfs per square mile of drainage area) is in the part of the basin underlain by permeable Quaternary and Pliocene sand and gravel deposits that mantle the uplands. During wet seasons these deposits absorb and store large amounts of rainfall in a water-table aquifer that slowly releases part of the water to the streams during dry seasons. Quaternary alluvium in lowland areas and Pliocene sandy deposits form water-table and artesian reservoirs respectively that also contribute to streamflow in dry season.

The northern half of the basin, which drains Eocene formations of clay, marl, and fine to medium sand, has the smallest dryweather yield, a minimum 7-day $Q_{2}$ streamflow of less than 0.05 cfs per square mile of drainage area.

9. Withdrawals from artesian aquifers will not significantly affect natural discharge to the streams. Pumping from water-table reservoirs near the streams will affect base flow, and therefore streamflow.

\footnotetext{
2 Minimum flow for 7 consecutive days occurring at average of 2-year intervals; has 50 percent probahility of being exceeded in a given year; used as an index of normal low flow.
} 
Detailed appraisals and analyses are needed to show where and how the hydrologic systems are controlled by the natural environment and what changes are taking place or will take place as man develops, uses, and otherwise manages the ground-and surface-water resources of the basin. Coordinated water studies according to area, county, or subbasin should be planned and systematically carried out to provide facts that will aid in sound development and management not only of the ground water but of the total water resource. These studies should include geologic mapping to learn about the lithology and the hydrology, quality-of-water work to delineate the occurrence of salt water and other parameters and their effects on water use, and collecting of data on withdrawals from wells and on water-level changes to help determine optimum aquifer yields.

Development of either ground water or surface water is feasible in the Pearl River basin from a hydrologic standpoint. The choice for the developer and the manager becomes one of economics based upon sound knowledge of water.

\section{PURPOSE AND SCOPE OF THIS REPORT}

This report is the result of an appraisal of geohydrologic conditions in the Pearl River basin. It is a contribution to the comprehensive river basin studies coordinated by the U.S. Army Corps of Engineers. The appraisal was made by the Water Resources Division, U.S. Geological Survey, on the basis of available knowledge. The report summarizes available information on the ground-water reservoirs, the surface water-ground water relationships, and the general availability of water supplies for future economic development of the basin. In Mississippi, similar basin studies were made for the Big Black and Pascagoula Rivers.

The primary purpose of the report is to describe the geologic and hydrologic framework and its relationship to availability, quantity, and quality of the water resources in the Pearl River basin. In scope it deals with the environmental conditions that effect rainfall disposition, average annual runoff (groundwater and streamflow), which represents the normal recoverable water supply; aquifer characteristics and number and depth of aquifers; quality of the various waters; utilization of water from the different sources; and potential sources of supply, including saline water. Detailed investigations of localities and areas will be necessary for the development of ground water or surface water for specific needs. Much of the information in this report was gained from studies under way or completed in cooperation with State and local agencies. 
Water is a dynamic resource that poses certain questions to its users. Where does it come from? Where is it going? How much is at a given place at a given time? What are its chemical and physical properties? How can it be kept clean and pure or, where polluted, be restored to a clean and pure state? Are floods a hazard to communities in the basin? How can the water resources of the basin be managed to meet all the conflicting needs of a developing economy-municipal, industrial, flood control, and recreational? These are questions posed over and again to planners, developers, and managers.

The data in this report will be needed in answering some of the questions, particularly as they relate to current water supplies and potential sources of water. In addition to describing the geology and ground-water conditions, the report describes the interrelationship of ground and surface waters, the chemical quality of the water, and the overall availability and potential of the resources. It is a summarization and analysis of prior reports and miscellaneous data collected from earlier cooperatively financed projects and other sources. An annotated bibliography of selected works is included.

\section{THE RIVER BASIN}

\section{LOCATION AND DEVELOPMENT}

The Pearl River basin is in the east-central, south-central, and southern parts of Mississippi and the southeastern part of Louisiana (fig. 1). From its source the river flows 363 miles to its outlet channels, the East and West Pearl Rivers. The East and West Pearl flow for 48 and 44 miles, respectively, and empty into Lake Borgne, which is connected by Mississippi Sound to the Gulf of Mexico. The entire basin drains an area of 8,760 square miles consisting of all or parts of 23 Mississippi counties and parts of three Louisiana parishes.

In addition to the generally abundant water resources, particularly the large potential ground-water supplies and the undeveloped flood flows and estuarine water, oil, natural gas, forest products, gravel, and clay are available in various parts of the Pearl River basin.

Population in the basin totaled 558,000 in 1960, of which about 223,000 was in the Jackson metropolitan area. The Jackson metropolitan population in 1965 was estimated at 250,900 , and anticipated future urban growth is expected to increase the population to about 379,500 by 1980 . Jackson's economy is built on its position as the State capital and the center for government, finance, services, distribution, and manufacturing. The economy of the remainder of the basin is based largely upon agriculture and related industries, including lum- 


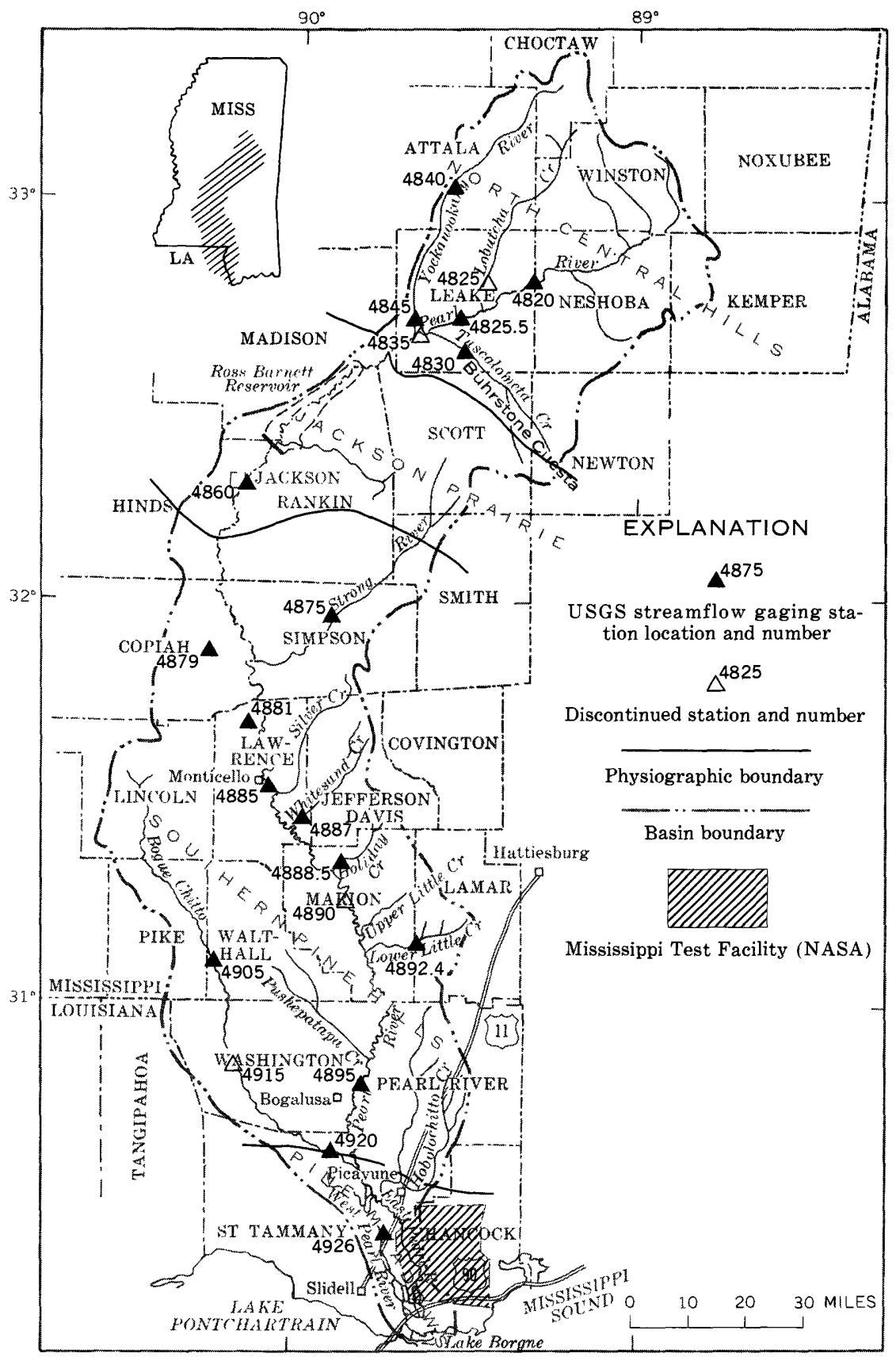

FIgURE 1.-Physiographic subdivisions, major drainage, and locations of streamflow gaging stations. 
ber, wood products, poultry products, and, in the central and southern parts, the oil and natural gas industry. Several major oil fields discovered since the late 1950's are being developed. Truck farming and stock raising are carried out on a large enough scale to supply much of the region with such products as strawberries, melons, vegetables, and poultry and dairy goods. Pecans and tung oil nuts are major money crops.

In the southern part of the basin, a large facility for testing of booster rockets by NASA has had a favorable economic impact on this area. About 2,500 people were employed at this facility in 1968. Many plants are being built or are planned for processing timber products, and oil and gas development is growing. Future urban growth in this area, according to an Economic Base Study, is projected to increase faster than in any other part of the Pearl basin.

Navigation development by the Corps of Engineers consists of a channel maintained at a water depth of about 7 feet from the mouth of West Pearl River to Bogalusa, La., and a 9-foot channel from the intracoastal waterway to the mouth of the East Pearl River.

Flood-control levees for protection of an industrial area and other land along both banks of the Pearl River at Jackson, Miss., were completed in 1968 and turned over to local interests for operation. Soil conservation districts have been active in assisting land owners in carrying out land-improvement projects. Three watershed projects have been authorized for operation in the river basin under Public Law 566.

\section{LANDFORMS AND DRAINAGE}

The land surface and the underlying rocks, soils, and other deposits form the framework on which and through which water moves. The shape, structure, and composition of this framework have a marked effect upon the movement, quantity, and quality of water available to the people of the Pearl River basin. The basin lies within the East Gulf Coastal Plain, which is physiographically subdivided into the North Central Hills (or Plateau), Jackson Prairie, Southern Pine Hills, and Pine Meadows districts (Fenneman, 1938, p. 68). Figure 1 shows the subdivisions.

The North Central Hills can be divided into two areas: a wide upland area to the north and northeast which has been cut by stream erosion into hills and valleys, and a narrower belt to the south and southwest called the Buhrstone Cuesta. Sandy formations of the Wilcox and Claiborne Groups underlie the wide upland surface and readily absorb and store large amounts of rain, making this upland a major catchment area for the valuable Eocene aquifers. The outcropping Tallahatta Formation (Claiborne), which east of the Pearl 
River is indurated and very resistant to erosion, forms the cuesta belt. Some of the hills in the particularly resistant part of the belt, east of the river, rise 200 feet or more above nearby streams and form a rugged, picturesque, and sparsely populated district. West of the river the peculiar character and effect of the formation on the topography are not so pronounced. The higher hills in this subdivision range in altitude from about 450 to 650 feet.

The descent from the North Central Hills to the gently rolling country of the Jackson Prairie is gradual. The prairie is a relatively narrow belt whose comparatively smooth topography results from the weathering of clayey formations of the Jackson and Vicksburg Groups. Vicksburg limestone crops out at the foot of an escarpment along the southern boundary of the belt and forms a less smooth surface than that of the clayey formations. Numerous prairielike tracts of excellent farmland lie in this belt 300 to more than 400 feet above sea level.

South of the Jackson Prairie is the Southern Pine Hills area, an extensive south-sloping upland with relief of 200 feet or more. Its north-facing scarp passes south of Jackson and extends eastward into Smith County. The region is underlain mainly by the sandy, porous, and therefore not easily erodible Citronelle Formation, which overlaps the older formations on the divides. The Citronelle generally rests on the Catahoula Sandstone and, farther south, on the Hattiesburg and Pascagoula Formations and certain unclassified Piocene deposits. In the Pearl River basin, the hills range in altitude above sea level from about 100 feet in the southern part of the subdivision to 500 feet or more in the northern part. The Southern Pine Hills form the recharge area for the ground-water reservoirs in the above-named formations. The Citronelle Formation is especially noteworthy for storing large volumes of rain that falls on the hills and ridges and then for slowly releasing ground water to maintain the substantial low flows of the streams in the basin south of Jackson. The larger tributaries of the Pearl River cross this dissected upland in wide flat-bottomed valleys with steep sides 100 to 300 feet high.

The Pine Meadows is a low-lying coastal district 25 to 40 miles wide which borders Mississippi Sound and Lake Pontchartrain and supports a growth of longleaf pine and slash pine. The landscape is one of low relief with large tracts of marsh and swamp. In some places sandy ridges separate shallow swales. The water table is at or near the surface, and the streams are sluggish and flow in tortuous channels. The water of streams and swamps is distinctly amber in color because of peaty matter with which it has been in contact.

Drainage patterns for the basin are shown in figure 1. Major tributaries to the Pearl River, listed in order from the northern part of the 
basin southward, are Lobutcha and Tuscalometa Creeks, Yockanookany and Strong Rivers, and Bogue Chitto. Smaller streams characterized by large base flows include the following creeks: Silver, Whitesand, Holiday, Upper and Lower Little, Pushepatapa, Hobolochitto, and West Hobolochitto.

\section{PRECIPITATION AND RUNOFF}

Precipitation takes either or both of two routes toward stream channels: one is over the land surface; the other is into the ground, moving downward to the zone of saturation to become ground water. A complex evaporation system draws large quantities back into the atmosphere. During and soon after rainfall, surface flow is substantial and constitutes a major part of streamflow. Rainfall intensity plays a large part in determining the proportion of overland runoff. In dry-weather periods, there is no overland runoff, and ground-water discharge provides the streamflow. A large percentage of the gross water resource escapes to the Gulf of Mexico as flood water, and hence is not stored and is unavailable as water supplies.

The average annual rainfall is about 52 inches in the northern third of the Pearl River basin and increases to 64 inches or more from the Jackson area to the mouth of the basin. (See fig. 2.) For the basin as a whole, rainfall totals about 26 million acre-feet per year. Most of the moisture for the rainfall is provided by the Gulf of Mexico. Warm moist airmasses moving in from the gulf are pushed up to high altitudes and lose much of their moisture as they encounter cooler, arctic airmasses moving southward.

Average annual evaporation from lake surfaces in the watershed generally ranges from less than 44 inches in the northern part to 48 inches in the extreme southern part. Free-water evaporation is a dependable index to potential consumptive use.

Average annual runoff in the basin ranges from about 16 to 26 inches (fig. 2). This is a measure of the quantity of water available under existing hydrologic conditions. The amount and rate of overland flow vary from one part of the basin to another because of the wide differences in topography and geology from place to place as well as in the amount and intensity of rainfall. Sand and gravel deposits, which underlie the lowlands and a large part of the uplands, shed less rainfall than do deposits of clay, marl, and fine sand. The sandier deposits take up and store large volumes of the rainfall, and under favorable hydrologic conditions they discharge some of it slowly during dry weather.

The base flow of streams is some measure of the quantity of water available from the contributing aquifer or aquifers without depletion 


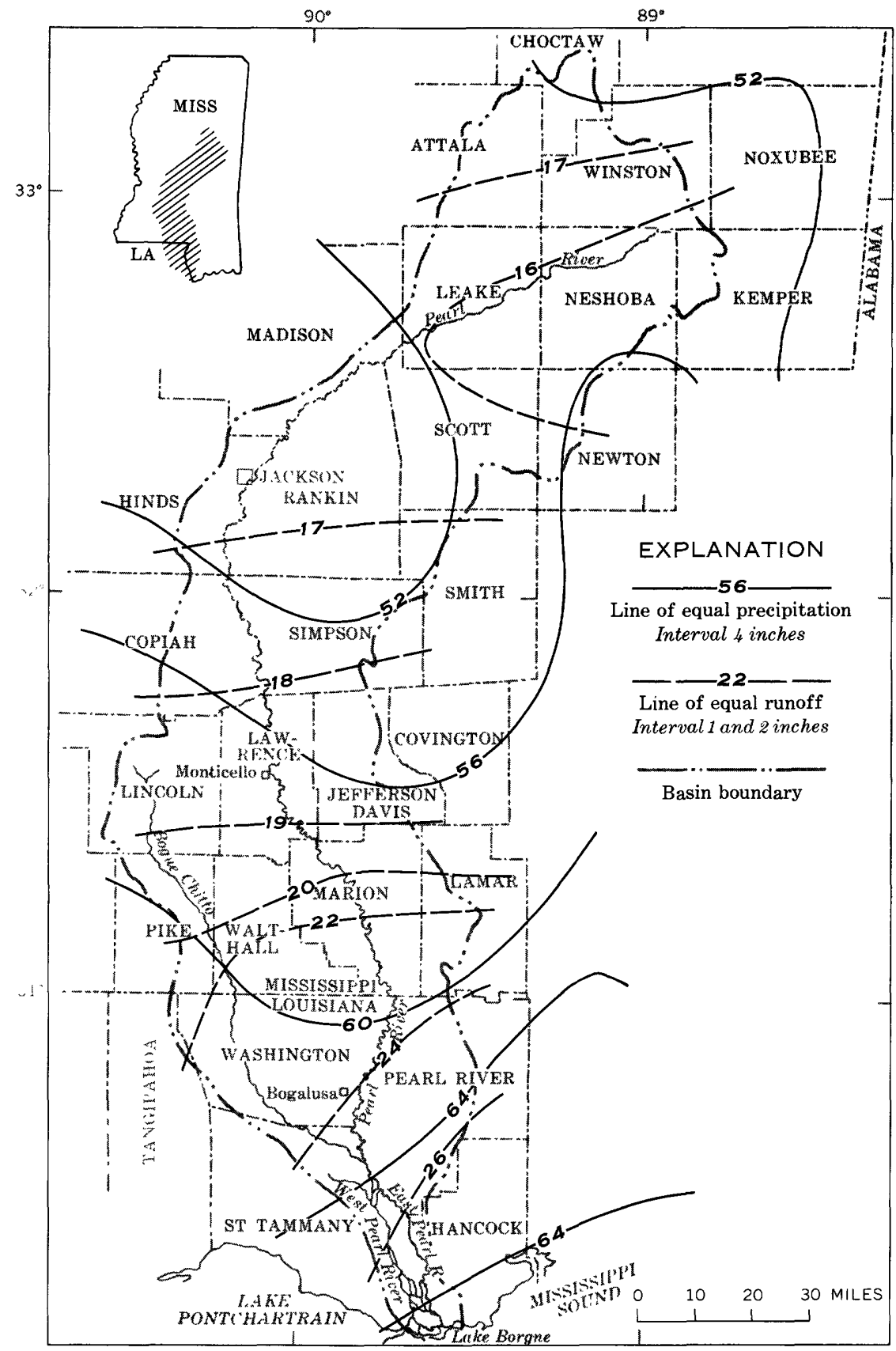

FIGURE 2.-Average annual precipitation and runoff. 
of the amount stored in that aquifer or group of aquifers. Several of the deeper aquifers which store large volumes of water in the Pearl basin receive rainfall from recharge areas outside the basin. Likewise, an unknown amount of ground water received as rainfall within the basin moves across topographic divides into areas outside the basin.

\section{GEOLOGIC FRAMEWORK}

Geologically, the Pearl River watershed is not a contained unit because the formations extend beyond the topographic divides into adjoining stream basins. The formations at the surface are sedimentary in origin and range in age from early Eocene to Holocene.

The function of the basin's hydrologic systems is closely associated with (1) geology (structure, lithology, thickness, and interfingering of formations, and changes in the sediments caused by weight of overlying strata); (2) physiography; and (3) climate. Probably the most striking natural features are the coastward dip and increase in thickness of deposits, the large number of massive beds of sand and clay and their lenticularity, and the wide range in permeability. The Mississippi River structural trough (just west of the Pearl basin), the Gulf Coast geosyncline (south of and parallel to the coast), and associated smaller features, such as the Wiggins uplift, the south Mississippi uplift, and the Jackson dome (fig. 3), have widespread significance with regard to the basin's framework and the hydrologic conditions therein.

Sand and clay in various proportions constitute nearly all of the immense prism of sedimentary deposits extending from the northern part of Pearl River basin to the coast; a few thin units of marl, limestone, and glauconitic and lignitic material also are present in several places. Individual sand beds are irregular in thickness, and few can be traced laterally more than about 5 miles, particularly those in the Pliocene-upper Miocene section. Predominantly sandy zones as differentiated from predominantly clayey zones are, however, correlatable over wide areas, some throughout much of the basin.

The formations dip southwestward at 20 to 80 feet per mile throughout the northern three-fourths of the basin except where they are interrupted by such structural features as the Jackson dome (pl. 1A) and many smaller salt domes. The rate of dip becomes steeper in the southern part of the basin, where pronounced downwarping toward the Mississippi River structural trough and the Gulf Coast geosyncline has resulted in a dip of 100 feet per mile or more (fig. 3). The Moodys Branch Formation, Jackson Group, of Eocene age, one of the more easily correlatable units in the basin, was used in constructing figure 3. 


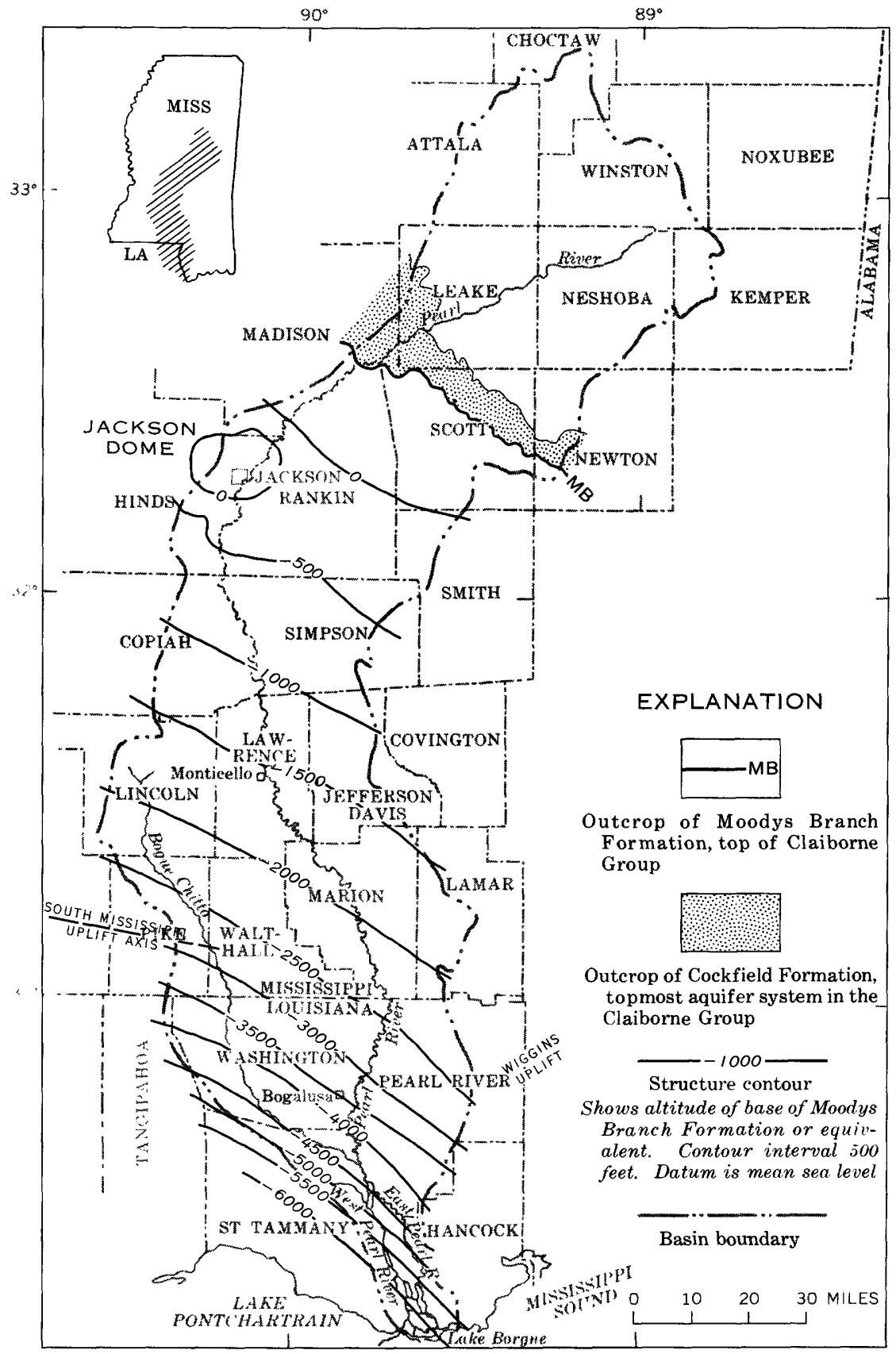

Figure 3.-Outcrop pattern and configuration of the base of the Moodys Branch Formation or equivalent and significant structural uplifts. 


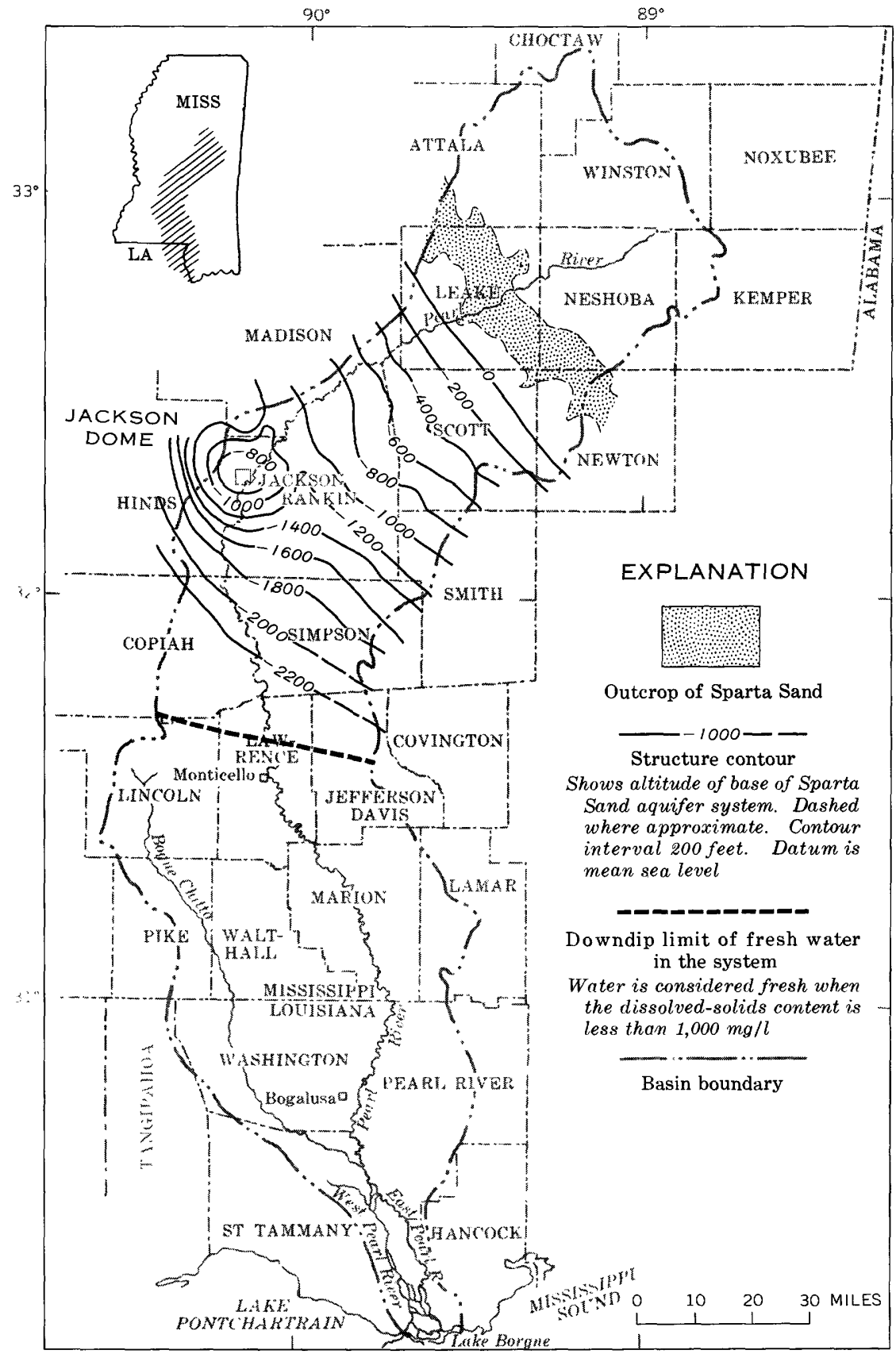

Fraure 4.-Outcrop pattern, configuration of the base, and extent of the freshwater part of the Sparta Sand aquifer system. 


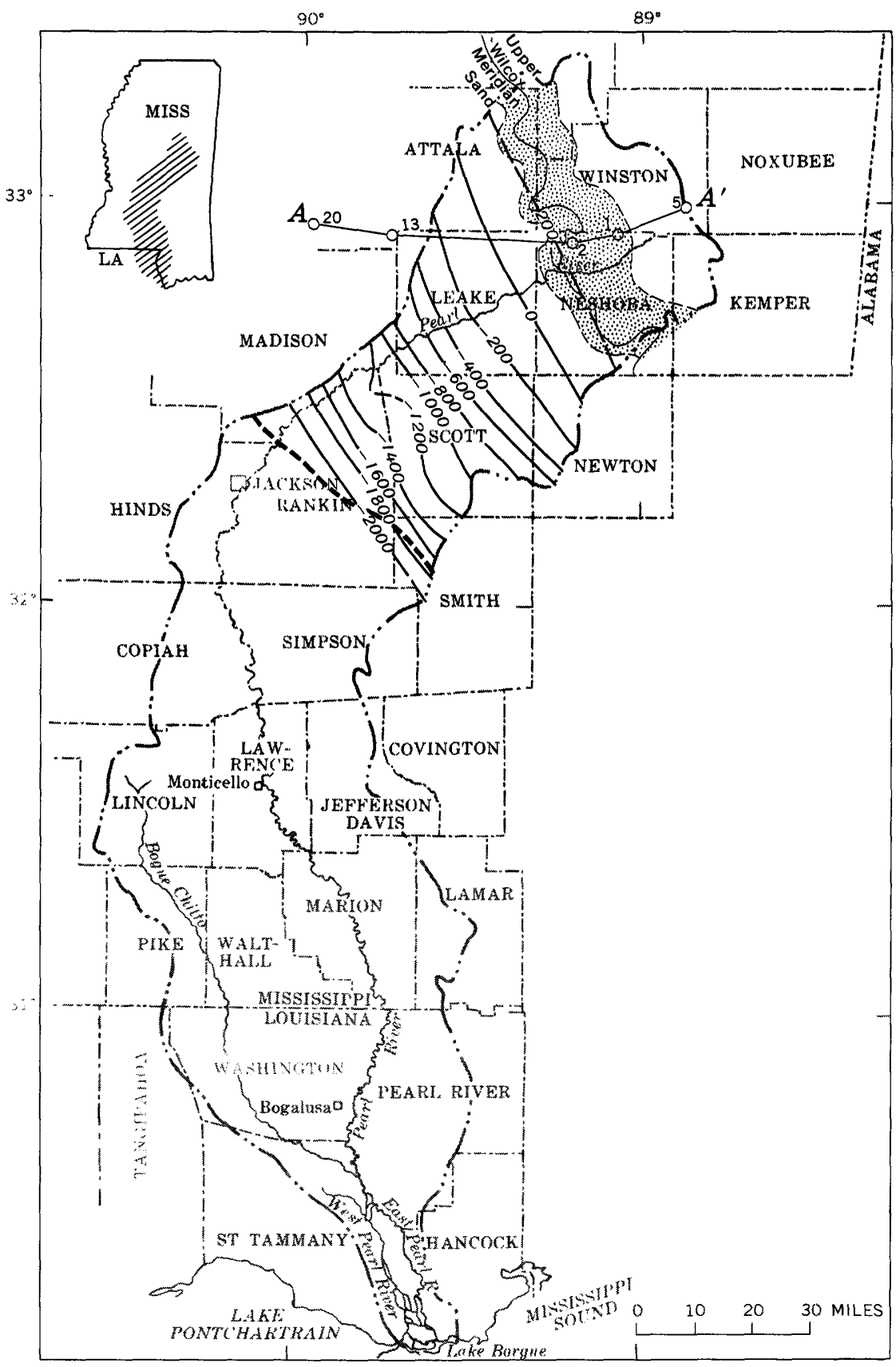

Figure 5.-Outcrop pattern, configuration of the base, and extent of the freshwater part of the Meridian-upper Wilcox aquifer system. Explanation and section $A-A^{\prime}$ are on facing page. 
EXPLANATION

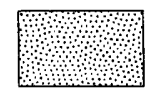

Outcrop of Meridianupper Wilcox aquifer

Structure contour

Shows altitude of base of Meridian-upper Wilcox aquifer system. Dashed where approximate. Contour interval 200 feet. Datum is mean sea level

Downdip limit of fresh water in the system

Water is considered fresh when the dissolved-solids content is

less than $1,000 \mathrm{mg} / \mathrm{l}$

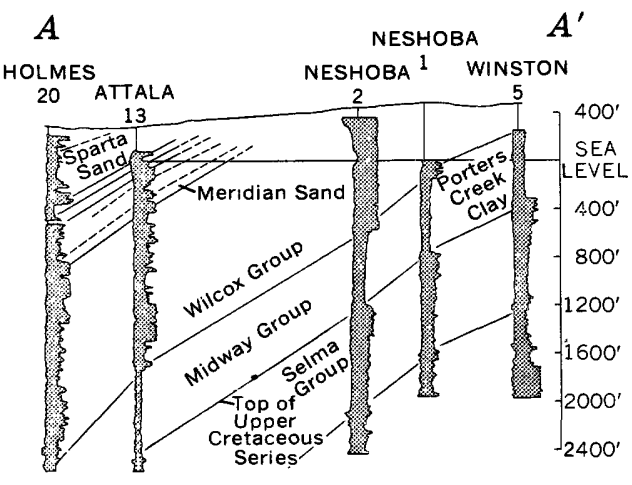

VERTICAL SCALE GREATLY EXAGGERATED

Geologic section

Basin boundary

$$
\mathrm{O}^{20}
$$

Test well for oil and number

Maps showing the outcrop belts of the Sparta Sand and the Meridian-upper Wilcox aquifer systems in the basin (figs. 4 and 5) also illustrate the southwestward dip of the respective systems and the downdip limit of fresh water in them. The Jackson dome interrupts the dip; the Sparta Sand, for example, has been uplifted 600 feet or more on the crest of the structure (pl. $1 A$ and fig. 4).

As the sediments accumulated offshore, the gulf bottom gradually sank under their weight, but the water in the gulf remained shallow. Compaction of sediments and further accumulation of detrital material resulted in marine deposition of thin to massive beds of clay, sand, and gravel and in long-continued subsidence to great depths during the Tertiary, particularly in the southern part of the Pearl River basin and adjacent areas (pl. $1 B$ ). In addition to showing the depth and thickness of the fresh-water section, plate $1 B$ also shows the lenticularity of the beds, the large number of water-bearing sands, and the dissolved-solids content, temperature, and head for many of the aquifers.

Significant changes that influence the occurrence and movement of ground water have occurred within the geologic framework since deposition of the sedimentary material. The deeper beds, for example, have been compacted by weight of the overlying sediments, and their porosity has therefore generally decreased. Wide ranges in porosity and permeability occur. The shallow Pleistocene and Holocene materials are less consolidated and have the highest permeabilities. 
The Quaternary alluvial deposits dip only gently seaward. In Louisiana and adjacent areas in Mississippi, the early Quaternary consists of interbedded red silt, sand, and gravel lying unconformably on blue and gray sediments of the Tertiary. Downdip from the outcrop the color becomes bluish and the sand more uniform in grain size, as described by Winner $(1963$, p. 7$)$. The deposits of late Quaternary age generally are buff to tan silt and sand that occur in stream valleys of upland areas and in backswamps along margins of tidal lakes and streams near the coast.

Ground-water reservoirs of high permeability occur in the Quaternary deposits and in the Pliocene Citronelle Formation. The part of the Pearl River basin having Quaternary and Pliocene sand and gravel terrace deposits underlain by Miocene clayey material produces the largest dry-weather streamflow in the entire watershed (pl. 2). This is because the shallow sandy deposits form water-table reservoirs that absorb and store large volumes of rainfall, a part of which is slowly released by gravity to become streamflow where valleys cut through the reservoirs.

The map (pl. 2) showing geohydrologic relationships, together with the geohydrologic sections (pl.1) and the base-of-fresh-ground-water map (fig. 6), can be used as a guide for determining availability of fresh water under the indicated environmental conditions.

\section{WATER RESOURCES OF THE BASIN}

Water resources of the Pearl River basin are generally plentiful, but the supply varies. Ground-water reservoirs are more productive in some areas than in other areas, and streamflows are scarce at times and excessive at others. The total average annual rainfall is approximately 26 million acre-feet. Although there are wide variations, ranging from droughts to periodic excesses caused by heavy rains and resulting in large flood flows that waste into the Gulf of Mexico, the aggregate water resource is large. This report concerns the part of the gross resource that is available on a sustained basis, excluding reuse of water as it moves down the basin. Data defining this quantity as well as that of floodwater are being collected by the U.S. Geological Survey.

The long-term aggregate dependable water supply for the basin under present conditions is estimated to be more than $3 \mathrm{bgd}$, or about 9,200 acre-feet per day. Three-fourths of this is in the lower third of the watershed, in Louisiana and southern Mississippi. With adequate storage, the recoverable water supply for the entire basin would 


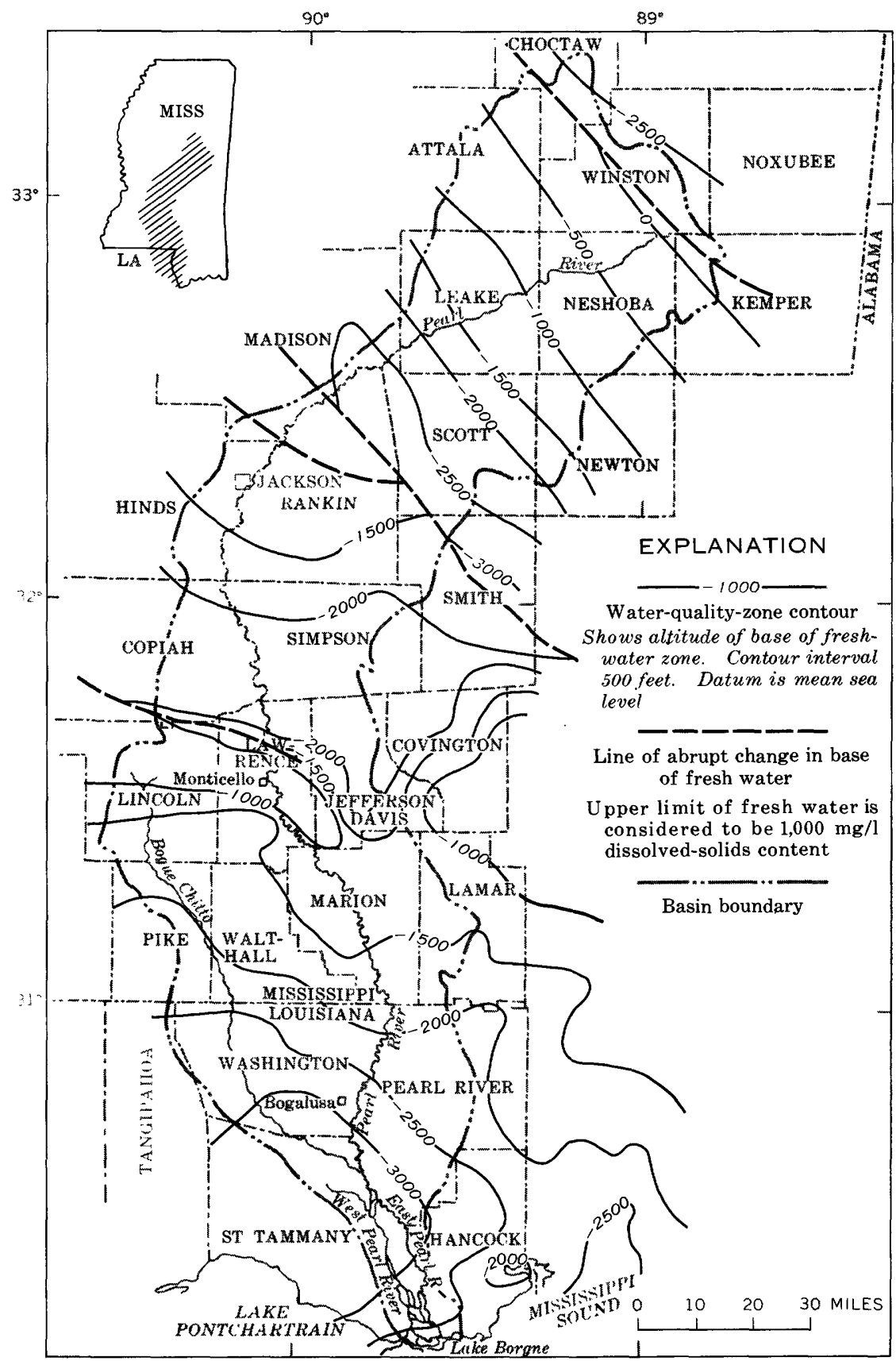

Figure 6.-Configuration of the base of fresh ground water. 
probably total 8 bgd ( 9 million acre-ft per yr). The dependable supply is not distributed uniformly throughout the watershed; much of it is held in immense ground-water reservoirs that occur in wide bands that cross the basin, part of it is in overflow from ground-water sources in upland areas, and part is in the Ross Barnett reservoir on Pearl River north of Jackson.

Nearly all the ground water is of good to excellent quality and requires little or no treatment. The chemical quality differs from place to place in individual aquifers, and from aquifer to aquifer, but at a given site it is virtually constant for each aquifer. Iron content locally is more than $0.3 \mathrm{mg} / \mathrm{l}$ in several of the aquifers; such excessive content is objectionable for some water uses. Water from the streams, except in tidal reaches where gulf water penetrates inland, is less mineralized than the ground water. Median dissolved-solids content for water from the streams was $50 \mathrm{mg} / \mathrm{l}$ at 9 sampling sites in the basin (fig. 7). Water quality is discussed in more detail in another part of this report.

Pollution is a problem of lesser or greater extent in certain reaches of some streams, particularly the Yockanookany River below Kosciusko, Miss., and the Pearl River below Jackson, Miss., and below Bogalusa, La.

\section{OCGURRENGE, EXTENT, AND USE OF THE AQUIFERS}

In appraising, developing, and managing a ground-water supply in any locality or area, three things must be resolved:

1. Location, depth, thickness, and extent of the source aquifer or aquifers.

2. Quality of the water, both chemical and physical.

3. Ability of selected aquifer or aquifers to satisfy the needs for which the water is intended.

Ground water in the Pearl River basin, although furnishing many industrial water supplies, all the municipal water supplies except for the corporate city of Jackson, and thousands of domestic and farm supplies, is still a generally undeveloped resource. Many deep aquifers have never been tapped. Total withdrawals are 50 to $60 \mathrm{mgd}$ for all uses; discharge from uncontrolled flowing wells is estimated at another $20 \mathrm{mgd}$. Total unused reserves are adequate to sustain an average use many times the present rate of withdrawal.

Fresh ground water (less than $1,000 \mathrm{mg} / \mathrm{l}$ dissolved-solids content) occurs from the surface to depths ranging from about sea level in the extreme northern end of the basin to more than 3,000 feet below sea level near the southern end (fig. 6). Some of the aquifers contain fresh water beneath Lake Pontchartrain, Lake Borgne, and Mississippi Sound. The Eocene section, from bottom to top, contains the Meridian-upper 
PEARL RIVER BASIN, MISSISSIPPI AND LOUISIANA

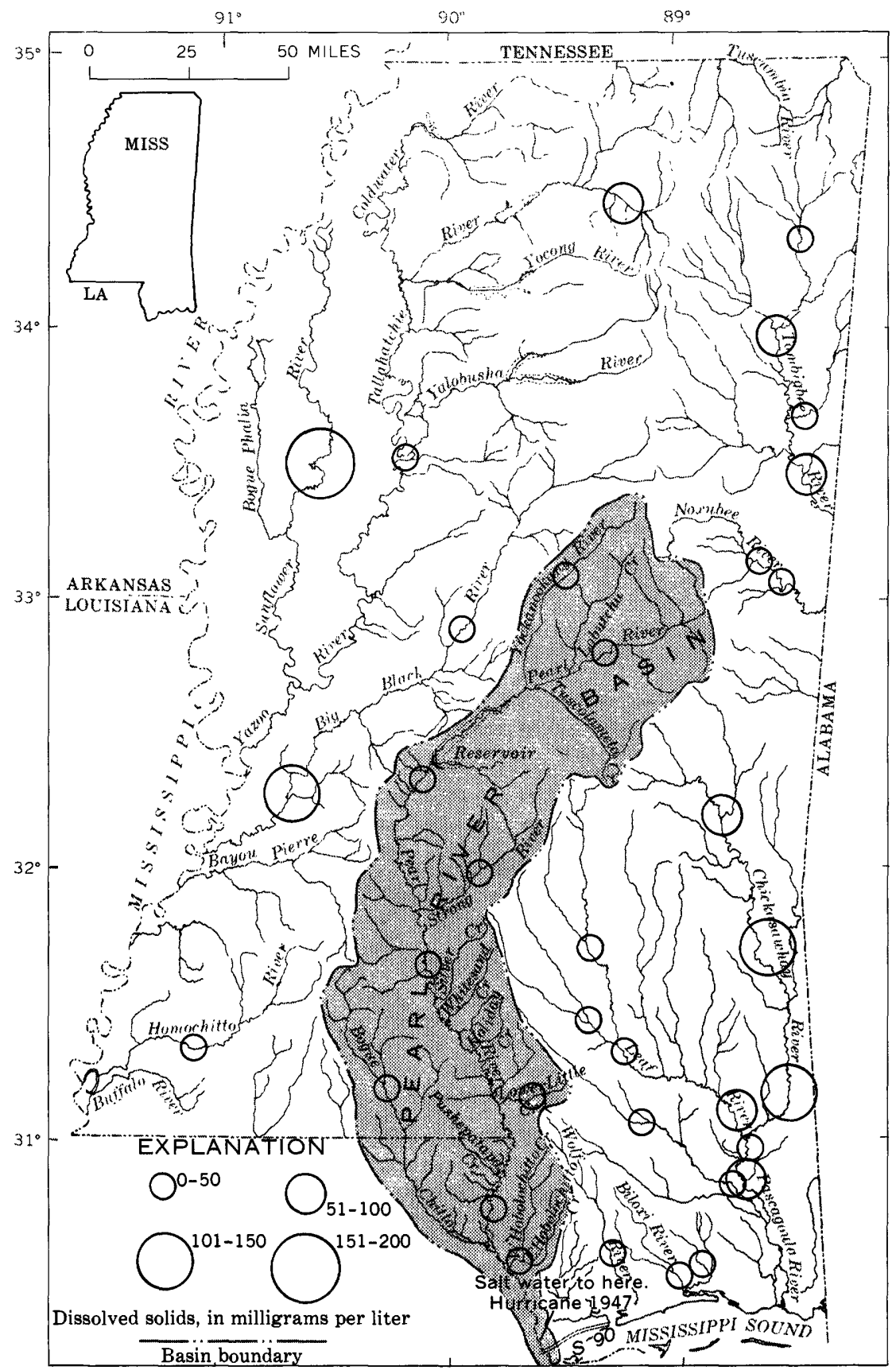

Figure 7.-Median dissolved solids at selected streamflow gaging sites, 1962-66. 
Wilcox, Sparta Sand, and Cockfield aquifer systems, and is the oldest group of deposits containing major sources of fresh ground water. These systems underlie the northern half of the river basin.

The older beds dip beneath successively younger beds in layer-cake fashion, and in many places several artesian aquifers are available from which to choose a water source. Moderately saline (3,000 to 10,000 $\mathrm{mg} / \mathrm{l}$ dissolved solids) to very saline $(10,000-35,000 \mathrm{mg} / 1$ dissolved solids) water occurs in each of the artesian aquifers many miles downdip from the outcrops, usually in a transition zone a few miles to 20 miles wide.

The middle and upper parts of the Eocene (Sparta Sand and Cockfield Formation) and the basal Miocene (Catahoula Sandstone) underlie the Pearl basin from the latitude of southern Rankin County to that of north-central Lawrence County. Nearly everywhere in this area one or more of the formations contains at least one good source of water supply. Most of the present water supplies are obtained from the shallower, Miocene aquifers in this area, and little or no development of the deeper, Eocene aquifers has been made.

From Lamar, Marion, and Walthall Counties, Miss., southward to the mouth of Pearl River, fresh water can be obtained from alluvium, coastal deposits, and high terrace deposits of Quaternary age and from sand units of Pliocene and Miocene ages. Moderate to large sources of soft water are available for expanding present municipal, industrial, and irrigation supplies or for developing new water supplies. Wells generally range in depth from about 200 to 2,000 feet (the deepest is about 2,700 ft. at Franklinton, La.). Pumping rates for most large wells, such as industrial wells, range from 1,000 to $1,500 \mathrm{gpm}$. The largest yields recorded are at NASA's Mississippi Test Facility, where a well 1,700 feet deep flowed more than $3,000 \mathrm{gpm}$ and in a pumping test produced 5,000 gpm with a 190-foot drawdown, and at Slidell, La., where two deep municipal-supply wells flowed more than $3,000 \mathrm{gpm}$ (one exceeded 4,000 gpm).

Table 1 is a summary of ground-water conditions and the geohydrologic environment as it influences the ground water-surface water relationships and water quality for the entire river basin. In addition to briefly describing the geology, character of the deposits, and their. water-bearing properties, it summarizes the availability, quality, and. present and potential use of ground and surface water, the ground water-surface water relationships, and pertinent data needs of the basin.

\section{RELATIONSHIP OF GROUND WATER TO STREAMFLOW}

Water is constantly moving on and beneath the land surface and to and from the atmosphere. The part of precipitation that seeps down- 
ward to the zone of saturation becomes ground water. Ground water moves downward and laterally through the aquifer systems under the influence of gravity from areas of recharge to places of discharge such as lakes, streams, springs, wells, and the ocean. The circulation of water through the stream systems and through the aquifer systems is necessarily of great concern to us because only from these parts of the hydrologic cycle can large water supplies be obtained. Ground-water reservoirs (aquifers) as well as surface reservoirs provide storage and therefore enhance the dependability of long-term water supply.

A close relationship exists between the geologic terrane and the hydrologic features of the Pearl River basin with respect to base streamflow. The largest values for minimum 7-day $Q_{2}$ streamflow per square mile of drainage area, for example, are in the part of the basin underlain by permeable sand and gravel deposits of Quarternary and Pliocene ages (pl. 2). Extensive blankets of these deposits cover the uplands on each side of the Pearl from northern Lincoln and southern Simpson Counties southward to Pearl River County, Miss., and southern Washington Parish, La. The water table in the shallow reservoirs fluctuates as the result of the effects of recharge and discharge. During wet seasons the water table rises as water is stored, and during dryweather periods the water table declines as water is discharged.

Discharge to streamflow occurs largely at the contact between the permeable sandy deposits and the underlying, less permeable clayey beds. The clayey beds prevent the ground water from moving downward and cause it to move laterally to places of discharge (seeps and springs). Such favorable geohydrologic conditions make the area of Quarternary and Pliocene sandy deposits underlain by Miocene clay one of high-yield base flow. In some places less extensive outcrops of Miocene sandy beds probably contribute lesser amounts of ground water to the streams.

The northern half of the basin drains a terrane characterized by clay, marl, and fine to medium sand. Unlike the southern part of the basin, the northern part does not have an extensive mantle of sand and gravel to store some of the rainfall and then slowly release the water to streams. Here, the minimum 7-day $Q_{2}$ streamflow is the smallest for the entire basin-less than $0.05 \mathrm{cfs}$ per square mile of drainage area, whereas the sandier terrane of the central and southern parts of the basin (pl.2) yields 0.05 to $0.20 \mathrm{cfs}$ per square mile of drainage area to minimum streamflow.

\section{AQUIFER AND WELL CHARACTERISTICS}

Aquifers in the Pearl River basin differ widely in their capacity for transmitting water. Coefficients of transmissibility determined from 
aquifer tests range from 3,500 to 480,000 gpd per $\mathrm{ft}$ (gallons per day per foot) (table 2 ; fig. 8 ). One test made in a minor aquifer showed a value of only $900 \mathrm{gpd}$ per $\mathrm{ft}$. Because of two variables-aquifer thickness and coefficient of permeability - whose product is the coefficient of transmissibility, the coefficient of transmissibility must be obtained either directly by an aquifer test or indirectly by multiplying the aquifer thickness by a known or assumed coefficient of permeability.

Field testing in several areas indicates that most permeability values in the basin probably range from 300 to 1,000 gpd per sq ft (gallons per day per square foot). The aquifer tests show permeabilities from less than 100 to more than $2,000 \mathrm{gpd}$ per sq $\mathrm{ft}$. The information is only a sampling and does not permit conclusions on the relative permeability of the various aquifers. However, many of the Miocene sand beds are very thick, which implies large transmissibility values. Aquifer transmissibility and available drawndown determine the withdrawal rate which can be expected for a well. Newcome (1967b, p. 22-27) presents an example, which also applies generally in the Pearl basin, that relates transmissibility to drawdown and pumping rate for wells in the adjacent Pascagoula River basin.

Measured or assumed values of aquifer characteristics have practical application in predicting the pumping rates for wells and the effects of water withdrawal. Harvey, Callahan, and Wasson (1964, p. 18) used average values of transmissibility from several aquifer tests to construct a graph of drawdown curves (fig. 9) for the Sparta Sand and the Cockfield Formation. The graph illustrates the amount of drawndown to be expected in these aquifers at various distances up to 10,000 feet from a well pumped at the rate of $1,000 \mathrm{gpm}$ for 1 year. This information can be applied in planning well spacing when developing a ground-water supply so that interference of wells can be kept within practical limits. The information is also useful in estimating withdrawal rates and pump settings in wells.

More than half the water-bearing units listed in table 2 are capable of maintaining pumping rates of $1,000 \mathrm{gpm}$ or more per well. Many aquifers are capable of rates greater than $2,500 \mathrm{gpm}$; however, few wells are constructed to furnish more than that amount. If the aquifer has a coefficient of transmissibility of $100,000 \mathrm{gpd}$ per $\mathrm{ft}$, then a 100 percent efficient well (12-in. diameter) pumped at $1,000 \mathrm{gpm}$ will have a drawdown of about 23 feet after 1 day of pumping; after 10 days the drawdown would be about 10 percent additional. If well effciency is less than 100 percent, the production rate will be decreased or the drawdown increased proportionately. 


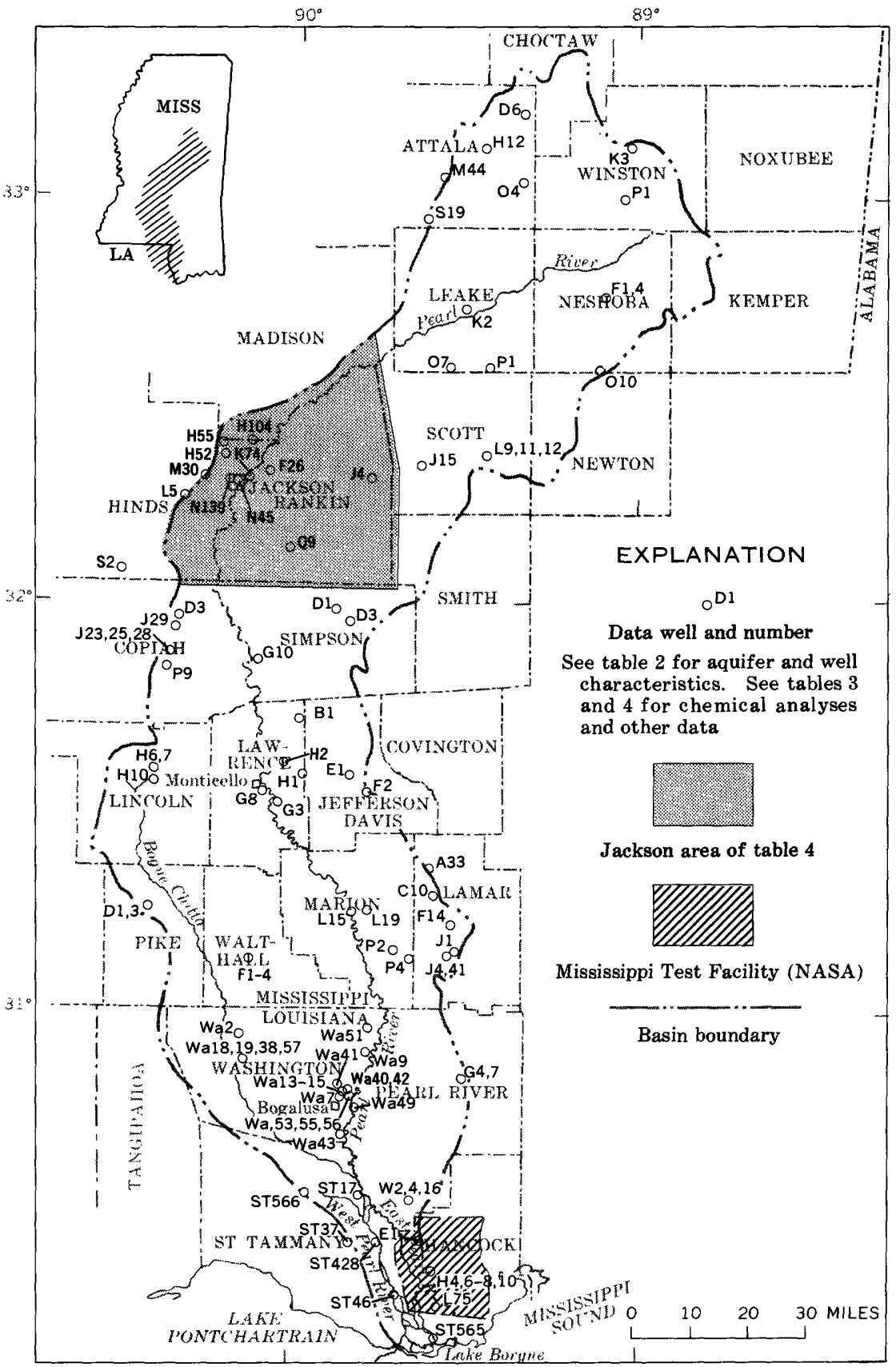

FrguRE 8.-Locations of aquifer-test and ground-water-sampling sites. 
TABLE 2.-Aquifer and

$\begin{aligned} & \text { USGS } \\ & \text { well No. }\end{aligned}$

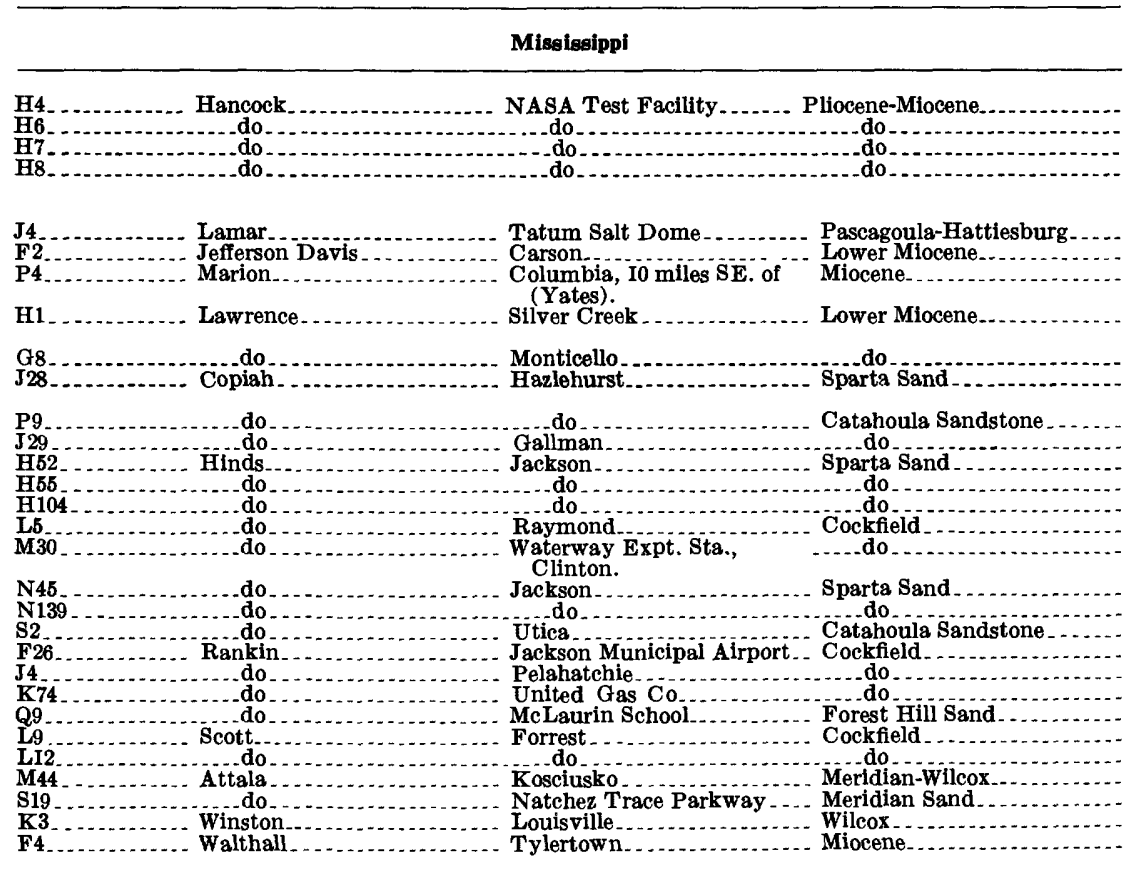

1 Length of interval; depth unknown. 


\section{well characteristics}

\begin{tabular}{|c|c|c|c|c|c|}
\hline \multirow{2}{*}{$\begin{array}{c}\text { Screened } \\
\text { interval } \\
\text { (ft below } \\
\text { land surface) }\end{array}$} & \multicolumn{2}{|c|}{ Coefficient of } & \multirow{2}{*}{$\begin{array}{c}\text { Pumping } \\
\text { rate } \\
\text { (gpm) }\end{array}$} & \multirow{2}{*}{$\begin{array}{l}\text { Specific } \\
\text { capacity } \\
\text { (gpm per } \\
\text { ft) }\end{array}$} & \multirow{2}{*}{ Remarks } \\
\hline & $\begin{array}{l}\text { Transmissibllity } \\
\text { (gpd per ft) }\end{array}$ & $\begin{array}{l}\text { Permeability } \\
\text { (gpd per sq ft) }\end{array}$ & & & \\
\hline \multicolumn{6}{|c|}{ Louigiana-Continued } \\
\hline $\begin{array}{c}104-170 \\
580-687 \\
688-769 \\
1,352-1,442 \\
609-748 \\
1,453-1,553 \\
1,446-1,514 \\
2,580-2,746 \\
2,108-2,180\end{array}$ & $\begin{array}{r}79,000 \\
75,000 \\
94,000 \\
44,000 \\
290,000\end{array}$ & 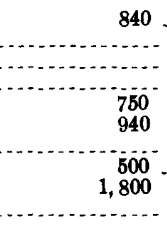 & $\begin{array}{l}1,000 \\
1,000 \\
1,100 \\
1,280 \\
1,650 \\
2,000 \\
1,800 \\
1,200\end{array}$ & $\begin{array}{r}24 \\
23 \\
25 \\
61 \\
28 \\
18\end{array}$ & $\begin{array}{l}\text { Industrial use. } \\
\text { Public supply. } \\
\text { Test made } 1942 . \\
\text { Public supply. } \\
\text { Industrial use. } \\
\text { Do. } \\
\text { Public supply. } \\
\text { Industrial use. } \\
\text { Public supply. } \\
\text { Irrigation well. }\end{array}$ \\
\hline \multicolumn{6}{|c|}{ Mississippi-Continued } \\
\hline $\begin{array}{c}1,803-1,873 \\
1,585-1,695 \\
1,371-1,443 \\
458-494 \\
532-580 \\
616-672 \\
920-1,000 \\
340-380 \\
200-230\end{array}$ & $\begin{array}{r}100,000 \\
200,000 \\
81,000 \\
116,000\end{array}$ & $\begin{array}{r}550 \\
1,670 \\
930 \\
685\end{array}$ & $\begin{array}{l}3,550 \\
5,000 \\
1,220 \\
5,860\end{array}$ & $\begin{array}{l}12 \\
26 \\
15 \\
47\end{array}$ & $\begin{array}{l}\text { Industrial use. } \\
\text { Do. } \\
\text { Public supply. } \\
\text { Industrial use. } \\
\text { Test well. } \\
\text { Public supply, test well. } \\
\text { Domestic and stock. }\end{array}$ \\
\hline $\begin{array}{c}732-747 \\
777-797 \\
860-910 \\
2,472-2,492 \\
2,557-2,577\end{array}$ & $\begin{array}{r}3,500 \\
50,000 \\
8,000\end{array}$ & $\begin{array}{r}1,000 \\
160\end{array}$ & $\begin{array}{r}350 \\
38\end{array}$ & $\begin{array}{l}2 \\
3 \\
2\end{array}$ & $\begin{array}{l}\text { Public supply. } \\
\text { Do. } \\
\text { Industrial use. }\end{array}$ \\
\hline $\begin{array}{l}237-330 \\
165-210 \\
627-687 \\
720-795 \\
760-810 \\
1,100-1,180 \\
585-635\end{array}$ & $\begin{array}{l}45,000 \\
30,000 \\
22,000 \\
80,000 \\
34,000 \\
35,000 \\
10,000\end{array}$ & $\begin{array}{l}940 \\
600 \\
320 \\
600 \\
460 \\
280 \\
180\end{array}$ & $\begin{array}{l}450 \\
160 \\
580 \\
400 \\
150 \\
240 \\
150\end{array}$ & $\begin{array}{r}7 \\
18 \\
19 \\
8 \\
4 \\
-\end{array}$ & $\begin{array}{l}\text { Public supply. } \\
\text { Do. } \\
\text { M.P.\& L. Rex Brown plant. } \\
\text { Do. } \\
\text { Hinds Water Co. } \\
\text { Public Supply Well } 2 . \\
\text { N. Well, Expt. Sta. }\end{array}$ \\
\hline $\begin{array}{r}714-774 \\
694-734 \\
267-307 \\
554-614 \\
542-592 \\
410-460 \\
395-415 \\
290-350 \\
290-350 \\
360-420 \\
420-460 \\
250-315 \\
1100\end{array}$ & $\begin{array}{r}50,000 \\
30,000 \\
37,000 \\
22,000 \\
13,000 \\
41,000 \\
900 \\
64,000 \\
62,000 \\
55,000 \\
9,000 \\
80,000 \\
100,000\end{array}$ & $\begin{array}{r}310 \\
460 \\
700 \\
380 \\
76 \\
360 \\
26 \\
490 \\
470 \\
740 \\
1,890 \\
1,000\end{array}$ & $\begin{array}{r}90 \\
250 \\
180 \\
290 \\
230 \\
190 \\
40 \\
365 \\
770 \\
1,000 \\
16 \\
895 \\
86\end{array}$ & $\begin{array}{r}14 \\
9 \\
6 \\
19 \\
14 \\
29 \\
39 \\
14\end{array}$ & $\begin{array}{l}\text { Laundry plant. } \\
\text { Cotton ofl mill. } \\
\text { Public supply. } \\
\text { Do. } \\
\text { Do. } \\
\text { Pipeline sta. } \\
\text { Public school. } \\
\text { Public supply. } \\
\text { Do. } \\
\text { Public supply, near library. } \\
\text { Picnic area. } \\
\text { Public supply. } \\
\text { Do. }\end{array}$ \\
\hline
\end{tabular}




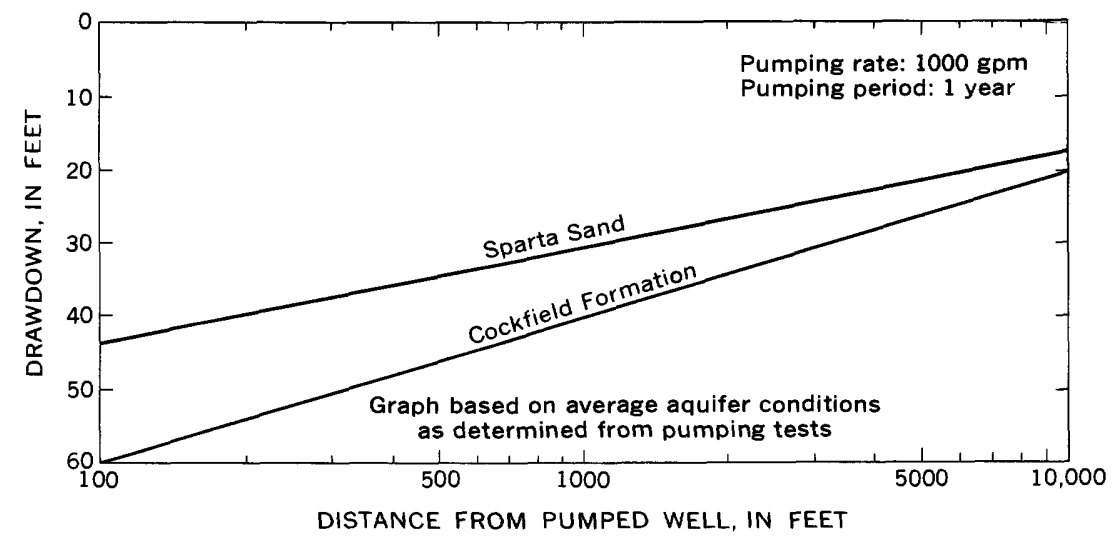

Figure 9.-Theoretical drawdown curves for the Sparta Sand and the Cockfield Formation. From Harvey, Callahan, and Wasson (1964).

Most wells are constructed to provide only a required amount of water, and seldom is the full potential of the aquifer utilized. Only 16 of the 39 wells listed in this report are pumped at rates greater than 500 gpm (table 2). Actually, well-production values in themselves are of limited worth in aquifer appraisals because of variables in well construction, including casing diameter, screen diameter, length and mesh size of the screen, and degree of development of the well. The key to maximum production rate is proper construction, including thorough development. Any aquifer having a coefficient of transmissibility as much as $25,000 \mathrm{gpd}$ per $\mathrm{ft}$ can yield as much as $2,000 \mathrm{gpm}$ to a properly constructed well where there is as much as 200 feet of available drawdown. If the transmissibility is larger, less drawdown is required to furnish the same amount of water.

The production rate of wells, particularly those wells where large water supplies are needed, should be tailored to fit both the wateruse requirements and the potential effect on the water source. Consideration as to both time and well spacing must be given to the distribution of withdrawals; otherwise, even the most abundant source of supply may prove inadequate. Well locations and pumping schedules should be consistent with economic considerations, so that well interference problems are at a minimum.

In many areas of the Pearl River basin, excellent means of distributing ground-water withdrawals are available-wells can be developed in different aquifers at specific sites. At almost any place in the southern part of the basin, five to 10 aquifers could be developed with batteries of wells. Two or more wells at a site also could be developed nearly anywhere in the central and northern parts of the basin; therefore, two or more aquifers could be used, provided the quality of the water is no great problem. Multiscreened wells are sometimes used, but they are not always satisfactory because head differentials and differ- 
ences in aquifer transmissibility, both of which allow interchange of water between screened sections, are detrimental to well performance in some situations.

\section{QUALITY OF THE WATER}

As applied to an aquifer, a stream, or any other water source, water quality means those characteristics that are distinctive in relation to some use such as drinking, manufacturing, food processing, irrigation, or recreation. Water quality is relative and must be associated with the intended use of the resource; it therefore has many meanings. Quality of the water in the Pearl basin, as elsewhere, is influenced by natural factors and by the activities of man.

Water contains dissolved solids derived from a variety of sources. For example, overland flow dissolves solids from the soil and rocks over which it passes. Storm water in streams reflects the chemical constituents derived from the gases in the atmosphere by rainfall and from the land surface by normal and flood flow. During dry-weather periods, the chemical quality of the low-flow stream water is quite similar to the quality of ground water seeping or flowing into the streams. Water that infiltrates the ground dissolves additional constituents from the subsoil and the deeper formations. Limestone and other readily soluble rocks contribute particularly large amounts of dissolved solids. Industrial and domestic wastes are other sources of dissolved constituents in water.

Ground water of good to excellent quality is available throughout the Pearl River basin. The shallower aquifers in some places contain water that causes corrosion and contains excessive concentrations of iron, but deeper aquifers in the same localities can provide satisfactory supplies. Nearly all the water is a soft, sodium bicarbonate type and generally has a low (less than $100 \mathrm{mg} / \mathrm{l}$ ) to moderate (100 to 500 $\mathrm{mg} / \mathrm{l}$ ) concentration of dissolved solids (tables 3 and 4). Exceptions are high (more than $500 \mathrm{mg} / \mathrm{l}$ ) dissolved-solids concentrations in water from the deep wells in the Wilcox aquifer and from a few wells each in the Sparta Sand, the Cockfield Formation, and the Forest Hill Sand in the Jackson area (table 4). U.S. Public Health Service "Drinking Water Standards" (1962), intended to apply only to drinking water used on common carriers engaged in interstate commerce and on other carriers subject to Federal quarantine regulations, are often used as a criterion for evaluating the suitability of all water supplies. These standards recommend that water contain less than 500 $\mathrm{mg} / \mathrm{l}$ dissolved solids but imply that where water of such quality is unavailable more highly mineralized water may be used.

Other information on water quality, in addition to that given in tables 3 and 4 , is given in table 1 , in figures $4-7$, and on plates 1 and 2. 
M30 CONTRIBUTIONS TO THE HYDROLOGY OF THE UNITED STATES

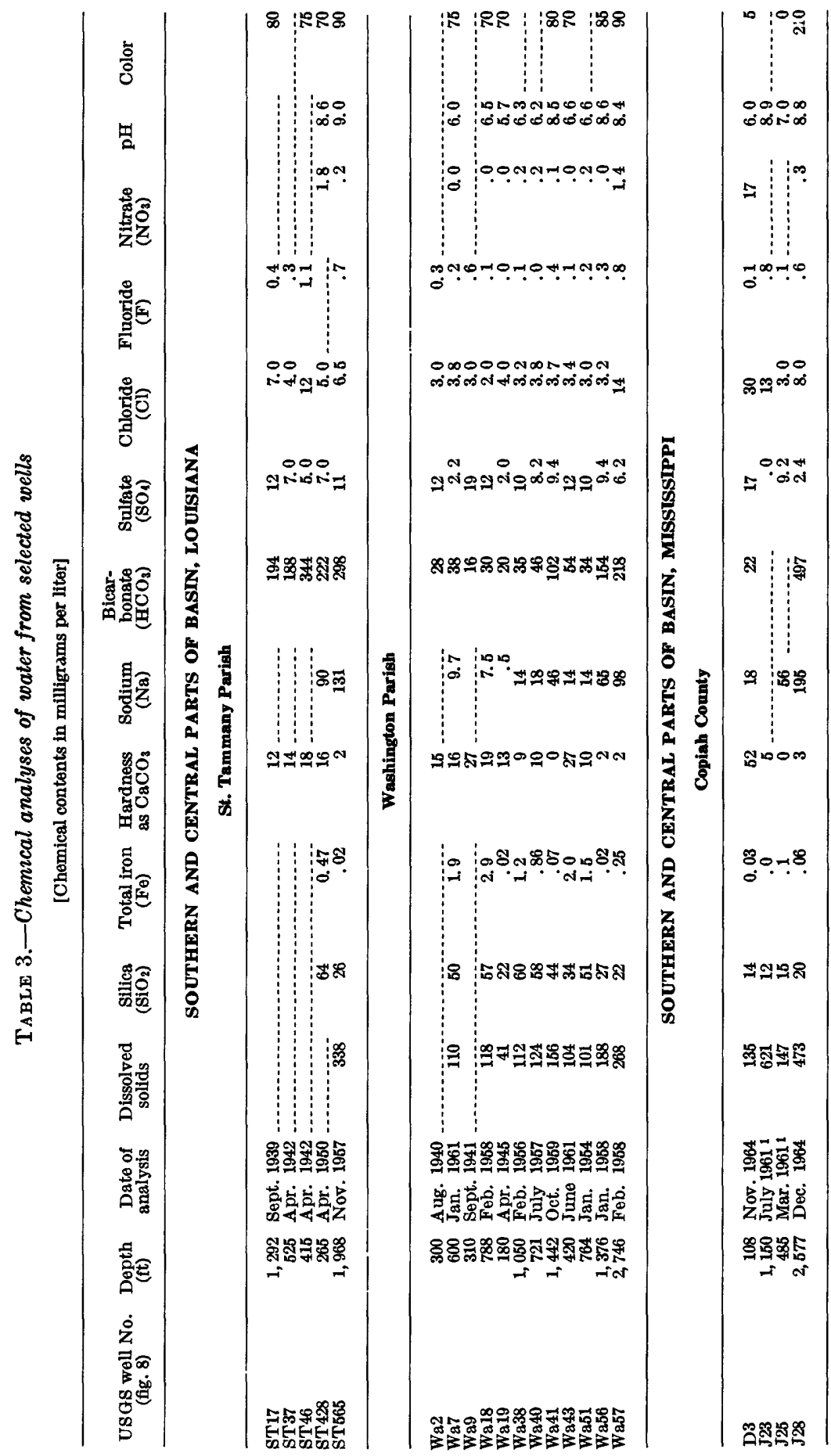


PEARL RIVER BASIN, MISSISSIPPI AND LOUISIANA M31

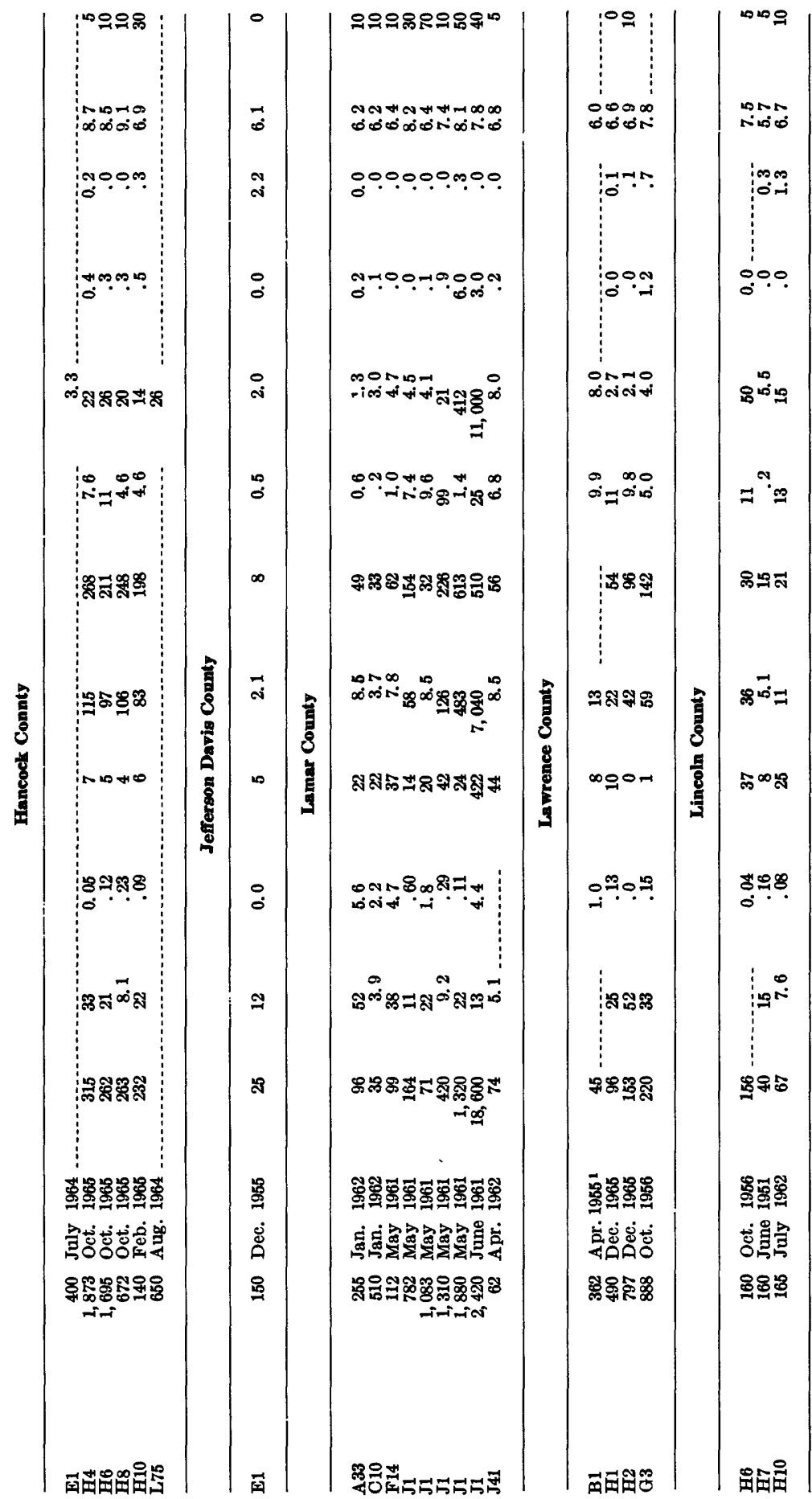




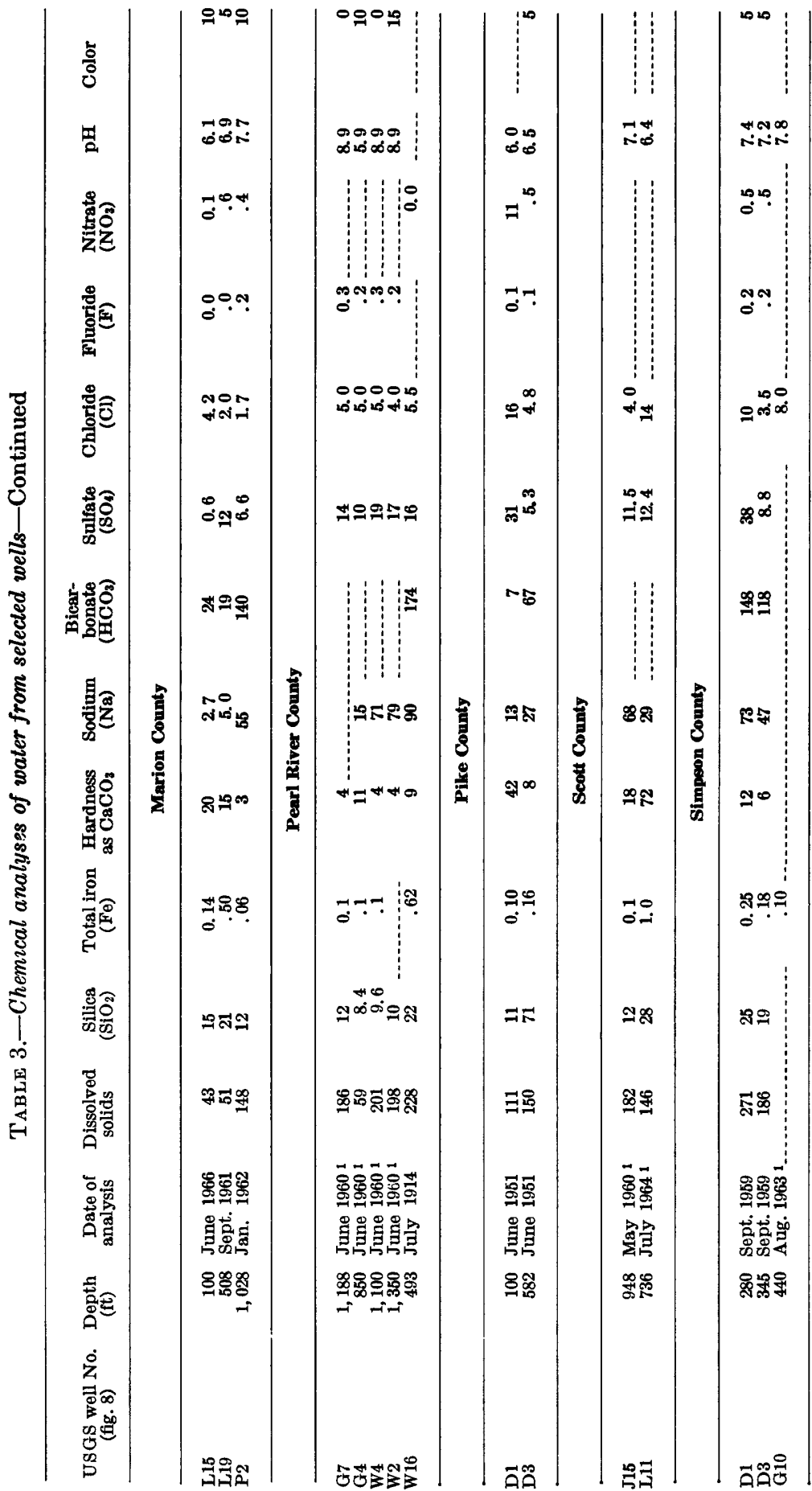


PEARL RIVER BASIN, MISSISSIPPI AND LOUISIANA M33

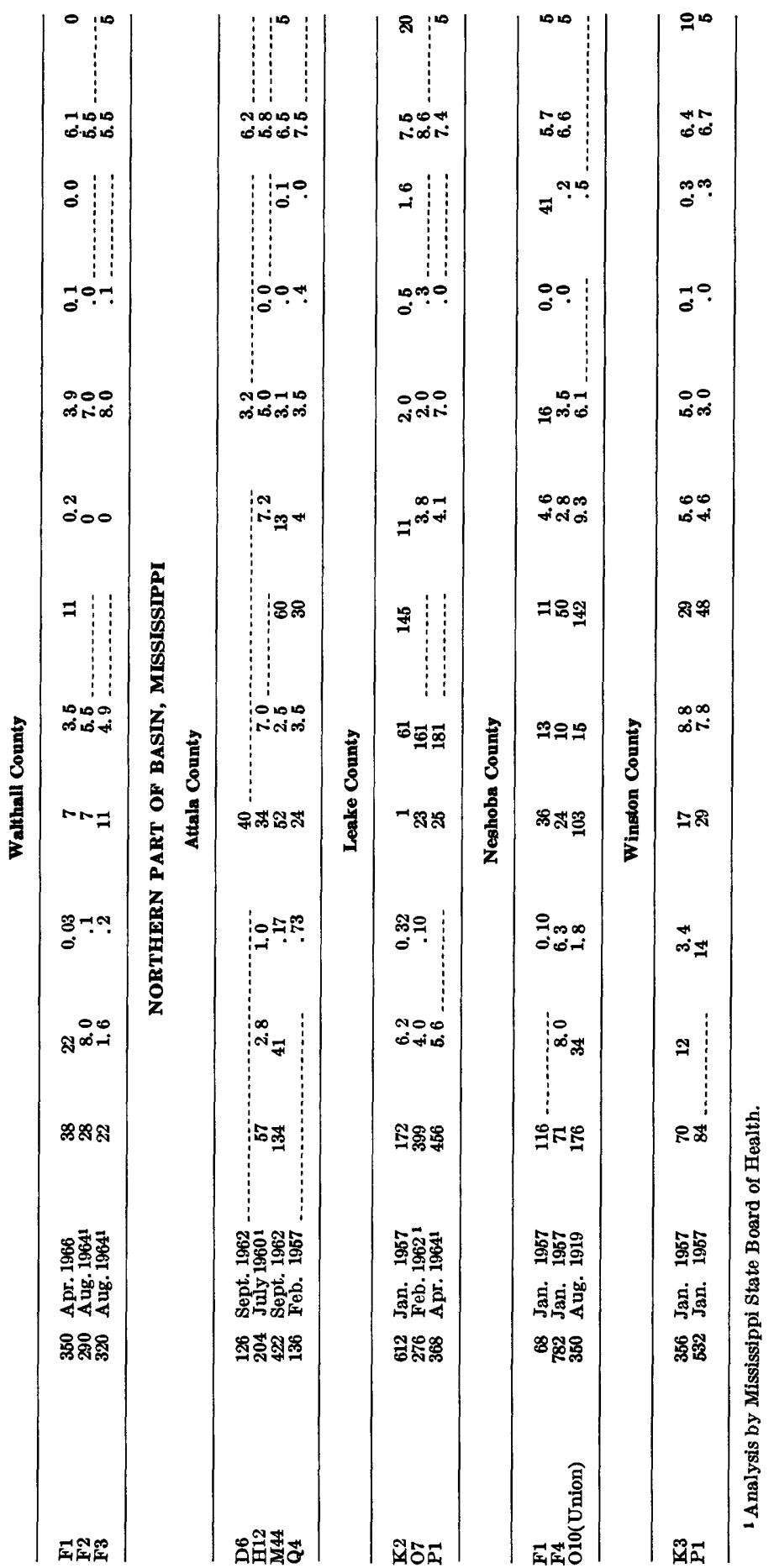


TABLE 4.-Minimum, median, and maximum values for chemical constituents and

[Data from Harvey, Callahan, and Wasson (1964); constituents

\begin{tabular}{|c|c|c|c|c|c|}
\hline \multirow[b]{2}{*}{ Water-bearing unit.- } & \multicolumn{2}{|c|}{ Wilcox group } & \multicolumn{3}{|c|}{ Sparta sand } \\
\hline & $\begin{array}{l}\text { Mini- } \\
\text { mum }\end{array}$ & $\begin{array}{l}\text { Maxi- } \\
\text { mum }\end{array}$ & $\begin{array}{l}\text { Mini- } \\
\text { mum }\end{array}$ & Median & $\begin{array}{l}\text { Maxi- } \\
\text { mum }\end{array}$ \\
\hline
\end{tabular}

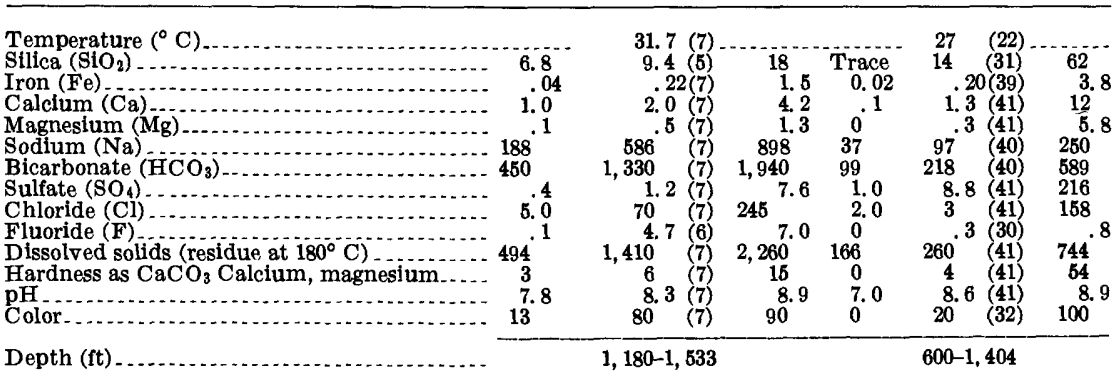

1 Number of determinations in parentheses.

Saline ground water is available in small to large amounts in deep aquifers of Late Cretaceous age in the northern part of the Pearl basin (probably from Leake and Neshoba Counties, Miss., northward), and in downdip extensions of each of the major Tertiary and Quaternary fresh-water systems in the central and southern areas of the basin. Large reserves of slightly saline $(1,000-3,000 \mathrm{mg} / 1$ dissolved-solids content) to moderately saline $(3,000-10,000 \mathrm{mg} / 1)$ ground water exist in one or more aquifers in Quaternary deposits in the extreme southern part of the basin. Water of varying degrees of salinity also occurs in stream channels, bayous, and bays near the coast, where they are affected by tides. Saline water as a resource is discussed as a subsequent topic.

Water available from the ground-water reservoirs is generally more mineralized than surface water. The dissolved-solids content of water in most of the aquifers in the basin is generally less than $200 \mathrm{mg} / \mathrm{l}$ and rarely exceeds $500 \mathrm{mg} / \mathrm{l}$. In the deeper aquifers, water has undergone various degrees of ion exchange and generally has a higher $\mathrm{pH}$ ( 7 to 9 ) and a higher dissolved-solids content. The dissolved-solids content is $300 \mathrm{mg} / \mathrm{l}$ or more in some aquifers in the basin's southern and central areas and 500 to $1,000 \mathrm{mg} / \mathrm{l}$ or more in a few aquifers in the Jackson area. The base of the fresh-water zone throughout the basin is illustrated by a contour map (fig. 6). The map is based on $1,000 \mathrm{mg} / 1$ dissolved-solids content as the upper limit for fresh water.

Chemical quality of the streamflow in the Pearl watershed is indicated by the map (pl. 2), which shows the maximum and minimum dissolved-solids content in the Pearl River at Bogalusa, La., and at Monticello and Jackson, Miss. Figure 7 shows the median dissolved- 
physical properties of ground water in the Jackson area, central part of the basin in milligrams per liter; alluvium values are median values]

\begin{tabular}{|c|c|c|c|c|c|c|c|c|c|c|}
\hline \multicolumn{3}{|c|}{ Cockfield formation } & \multicolumn{3}{|c|}{ Forest Hill sand } & \multicolumn{3}{|c|}{ Catahoula sandstone } & \multicolumn{2}{|c|}{ Alluvium } \\
\hline $\begin{array}{l}\text { Mini- } \\
\text { mum }\end{array}$ & Median 1 & $\begin{array}{l}\text { Maxi- } \\
\text { mum }\end{array}$ & $\begin{array}{l}\text { Mini- } \\
\text { mum }\end{array}$ & Median 1 & $\begin{array}{l}\text { Maxi- } \\
\text { mum }\end{array}$ & $\begin{array}{l}\text { Mini- } \\
\text { mum }\end{array}$ & Median 1 & $\begin{array}{l}\text { Maxi- } \\
\text { mum }\end{array}$ & $\begin{array}{l}\text { Pearl River } \\
\text { Valley }\end{array}$ & $\begin{array}{l}\text { Big Black } \\
\text { River } \\
\text { Valley }\end{array}$ \\
\hline $\begin{array}{c}5.7 \\
0 \\
.4 \\
0 \\
17 \\
72 \\
.8 \\
6.5 \\
0 \\
209 \\
2 \\
7.5 \\
5\end{array}$ & $\begin{array}{rr}23.6 & (24) \\
12 & (10) \\
.99(27) \\
1.6(29) \\
1.0(29) \\
135 \quad(29) \\
260 & (30) \\
33 & (30) \\
21 & (30) \\
38.15(22) \\
385 & (28) \\
8.5 & (30) \\
8.4(28) \\
20(29)\end{array}$ & $\begin{array}{c}16 \\
11 \\
34 \\
12 \\
529 \\
1,240 \\
255 \\
52 \\
4.4 \\
1,310 \\
107 \\
8.9 \\
700\end{array}$ & $\begin{array}{c}5.5 \\
.04 \\
.6 \\
.3 \\
55 \\
154 \\
0 \\
3.5 \\
.1 \\
270^{.0} \\
2 \\
7.0 \\
0\end{array}$ & $\begin{array}{rrr}22.2 & (14) \\
8.5 & (13) \\
.18(14) \\
2.4(15) \\
3.0(15) \\
349 \\
479 \\
376 & (15) \\
20 & (15) \\
10 & (15) \\
10.5 & (15) \\
113 & (14) \\
20 & (15) \\
8.3 & (15) \\
37 & (15) \\
37\end{array}$ & $\begin{array}{l}35 \\
9.0 \\
48 \\
26 \\
289 \\
692 \\
214 \\
109 \\
4.0 \\
791 \\
227 \\
8.7 \\
320\end{array}$ & $\begin{array}{l}41.04 \\
2.2 \\
1.4 \\
25 \\
25 \\
63 \\
16\end{array}$ & $\begin{array}{rr}20 & (3) \\
44 & (3) \\
& (34 \\
.84 & (4) \\
9.4 & (4) \\
3.5 & (4) \\
165 & (4) \\
280 & (4) \\
74 & (4) \\
35 & (4) \\
& 3 \\
452 & (1) \\
452 & (4) \\
30 & (3) \\
6.6 & (2) \\
7 & (2)\end{array}$ & $\begin{array}{c}69 \\
21 \\
16 \\
8.8 \\
185 \\
335 \\
93 \\
59\end{array}$ & $\begin{array}{c}18.3 \\
6.0 \\
15 \\
21 \\
8.7 \\
70 \\
44 \\
102 \\
72 \\
327 \\
38 \\
88 \\
6.3 \\
65\end{array}$ & $\begin{array}{l}18.3 \\
15 \\
50^{\circ} .04 \\
24 \\
16 \\
244 \\
22 \\
10 \\
0.3 \\
308^{\circ} \\
244 \\
8.5 \\
65^{\circ}\end{array}$ \\
\hline & $295-1,505$ & & & $167-653$ & & & $110-240$ & & 31 & 55 \\
\hline
\end{tabular}

solids content of water at 9 streamflow gaging sites in the Pearl River basin compared with median content at gaging sites in other watersheds in Mississippi. In general, the dissolved-solids content of surface water in the Pearl River basin ranges from about 30 to $75 \mathrm{mg} / 1$, lower than that of surface water in any of the other major watersheds.

\section{SALINE WATER AS A RESOURCE}

Saline water (containing more than $1,000 \mathrm{mg} / \mathrm{l}$ dissolved solids) occurs at some distance downdip in most of the aquifers described in this report (figs. 4 and 5). Salinity increases with depth and also with distance from the recharge or water-table areas in which the artesian reservoirs are at or near the surface. Near the coast, saline water occurs temporarily in some of the shallow sandy deposits because of their contact with salty gulf water, particularly during hurricanes. Large potential sources of water supply are available in the deeper, slightly to moderately saline aquifers, and their use should be considered where fresh ground water may not be adequate for future needs. Where feasible, water of inferior quality, instead of first quality, could be used for certain industrial processes including cooling.

The fresh to moderately saline Pearl estuary is a potential watersupply source for certain uses during parts of the year. Sound development and management of the estuarine area would first require detailed study of the quality changes, including how the fresh water moving downstream mixes and moves with the saltier waters. Knowledge is also needed about the manner in which the salt-water front advances upstream during periods of decreasing streamflow and retreats downstream during increasing streamflow. Occasional large storms and high 
tides force gulf water several miles upstream to U.S. Highway 90 or beyond.

The process of desalination is being refined and improved, and eventually, desalting large volumes of saline water for certain first-quality needs may become economical. Desalination would be more practicable for saline estuarine water and ground water on the coast or in inland areas where the water is only slightly saline $(1,000$ to $3,000 \mathrm{mg} / 1)$ or moderately saline $(3,000$ to $10,000 \mathrm{mg} / \mathrm{l})$ than it would be for gulf water $(10,000$ to $35,000 \mathrm{mg} / \mathrm{l})$.

Artesian head in the saline-water aquifers, which are several hundred feet to 2,000 feet (or more) deeper than the base of fresh water (fig. 6), probably is sufficient in some areas to raise the water to as much as 200 feet above sea level. The surface of the saline-water zone is very irregular, and in some places near the coast, saline-water aquifers occur between fresh-water aquifers. At present, not enough information is available on degree of salinity and other parameters to allow detailed mapping of the salt-water surface.

\section{KNOWLEDGE NEEDED FOR MANAGEMENT AND PLANNING CONSIDERATIONS}

In order to make wise decisions, water planners, developers, and managers require scientific facts about the hydrologic cycle, the changes in the environment of water, the waste-disposal problems, and the alternatives of sources of supply. Knowledge is needed in the Pearl River basin about low-flow frequency, bank storage, floods and floodplain hydrology, mechanics of ground-water movement, sources of recharge, properties of aquifers, chemical characteristics of water, and water in its natural environment as compared with water altered by man's use. Use of such available information will enable well-informed decisions to be made on water management and planning considerations, for example whether or not a dam should be built at a particular site, whether one large dam or a series of smaller dams should be built for flood control and other uses, and whether certain ground-water reservoirs should be used for storage of excess surface water where conditions are favorable.

The design of specific water-supply developments in almost any area of the basin will require special studies to determine the hydraulic and chemical characteristics of aquifers and streams in the areas of development and to predict the effects of such developments. Needs for this kind of information have been recognized by many water-development and water-management agencies. Studies have been and are being sponsored by the U.S. Army Corps of Engineers to determine the feasibility of developing ground-water supplies in conjunction with 
or in lieu of surface-water supplies in areas of proposed multiplepurpose reservoirs and to determine the effect of the surface reservoirs on the ground-water regimen.

Ground-water reservoirs in the Pearl River basin are especially important because they provide storage and transmission facilities in immense multiple artesian systems that are available to be tapped throughout wide areas for water supplies, and in shallow water-table systems, which largely control the dry-weather flow of streams. Both types of systems greatly enhance the dependability of long-term water supply and should be considered by planners and developers of water resources. Advantages of underground reservoirs are that they nearly eliminate evaporation, stabilize the water temperature, maintain uniform quality, and provide immense reserve water supplies that can be utilized during dry years. Under scientific management, the large potential source of water in the widespread shallow sand and gravel deposits, for example, could be further increased by storing surplus storm water in them and by controlling withdrawals so that the underground reservoirs could be utilized year after year.

Precipitation and runoff are sizeable, and the hilly terrain in parts of the central and southern areas of the basin provides favorable sites for surface reservoirs. The development of recreational localities centered on surface impoundments in certain scenic and sparsely populated areas would appear feasible for planning consideration.

In a few places, the dry-weather streamflow is inadequate to assimilate municipal and industrial wastes that are or may in the future be discharged into the streams. In order to ensure the recreational and esthetic values of the streams and to avoid inflicting future hardships on downstream water users, additional water for dilution will be needed. Ground-water sources might be utilized in several places to provide needed low-flow augmentation. Such use of ground water might be feasible in some places where surface storage solely for wastedilution purposes would not be economically feasible. Decisions would have to be made on the cost of using ground water versus the cost of using surface storage and versus the cost of a high degree of treatment of the wastes.

An Economic Base Study showed that less than 1,000 acres in the Pearl River basin were irrigated in 1964. Supplemental irrigation is practiced on certain truck farms in Copiah and adjacent counties and in Pearl River County in Mississippi and in some areas in Louisiana. Usually the supplemental supply is developed from wells or ponds near or on the irrigated tracts, thus eliminating costly pipelines or other means of delivering water to the fields. 


\section{ANNOTATED BIBLIOGRAPHY}

Boswell, E. H. Moore, G. K., MacCary, L. M., and others, 1965, Cretaceous aquifers in the Mississippi embayment, with discussions of quality of the water, by H. G. Jeffery : U.S. Geol. Survey Prof. Paper 448-C, 37 p., 8 pls., 27 figs. Defines and describes the 11 Cretaceous water-bearing units in the 45,000square-mile embayment. Describes water quality in general and according to units. Includes five regional geologic sections and several maps of various formations showing areas of outcrop, configuration of the top surface, areas of present and potential water use, piezometric surfaces of water in aquifers, areas of artesian fiow, and thickness and percentage of sand.

Boswell, E. H., Thomson, F. H., and Shattles, D. E., 1970, Water for industrial development in Clarke, Jasper, Lauderdale, Newton, Scott, and Smith Counties, Mississippi : Jackson, Mississippi Research and Devel. Center, 62 p. Gives detailed information on availability, chemical quality, and physical characteristics of ground water and surface water in the six-county area. Contains 32 illustrations and nine data tables. Included are six geohydrologic sections, four fiood profiles, and graphs showing duration of low streamfiow, relationship of dissolved solids to discharge, and time-drawdown data of aquifers. Thickness of the fresh-water section averages 1,500 feet and is as much as 3,500 feet in Smith County.

Brown, G. F., and others, 1944, Geology and ground-water resources of the coastal area in Mississippi : Mississippi Geol. Survey Bull. 60, 232 p. Outlines the physiographic features, the geologic formations and their water-bearing properties, and the history of ground-water development, and gives a summary of ground-water resources for George, Hancock, Harrison, Jackson, Pearl River, and Stone Counties. Contains tables of well records including extensive well logs, water analyses for each county, several geologic sections, and a geologic map of the coastal area. Describes the alluvial plain of the Pearl River, the southward-dipping formations, and the conditions for fiowing artesian wells. Presents data on artesian head, which has declined substantially in areas where uncontrolled flowing wells are prevalent.

Cardwell, G. T., Forbes, M. J., Jr., and Gaydos, M. W., 1966, Progress report on the availability of fresh water, Lake Pontchartrain area, Louisiana: Louisiana Geol. Survey and Dept. Public Works Water Resources Pamph. 18, 24 p. 1 pl., 3 figs. A preliminary analysis of data collected during a two year appraisal of the potential ground- and surface-water sources for needed additional water supply in the New Orleans area. Describes findings of 10 test borings in and adjacent to Lake Pontchartrain; borings reveal large fresh-water aquifers. Describes duration and quality of streamflow north of the lake to West Pearl River.

Cushing, E. M., 1966, Map showing altitude of the base of fresh water in coastal plain aquifers of the Mississippi embayment: U.S. Geol. Survey Hydrol. Inv. Atlas HA-221. Shows by contour lines the altitude of the base of fresh water (water with less than $1,000 \mathrm{mg} / \mathrm{l}$ dissolved-solids content) according to geologic units. Shows areas where mineralized water overlies fresh water. Short text explains the atlas, which describes an area extending from southern Illinois to the latitude of Jackson, Miss., including parts of nine States.

Cushing, E. M., Boswell, E. H., and Hosman, R. L., 1964, General geology of the Mississippi embayment: U.S. Geol. Survey Prof. Paper 448-B, 28 p., 2 pls., 10 figs. Summarizes post-Paleozoic geologic history of the embayment. Gives 
general description and water-bearing properties of geologic units ranging in age from Cretaceous to Quaternary. Includes stratigraphic columns, a fence diagram, four regional sections, and five structural-contour maps.

Cushman, J. A., 1923, The Foraminifera of the Vicksburg Group: U.S. Geol. Survey Prof. Paper 133, p. 11-71. Gives detailed descriptions of many species and varieties of Foraminifera and has eight plates illustrating several species. Describes the type localities for the formations in the Vicksburg Group and summarizes environmental conditions at the time the formations were deposited.

Eargle, D. H., 1968, Stratigraphy and structure of the Tatum Salt Dome area, southeastern Mississippi and northeastern Washington Parish, Louisiana, in Mattox, Richard B., ed., Saline deposits: Geol. Soc. America Spec. Paper 88, p. 381-405. Describes stratigraphy and structural features of a 3,000-squaremile area centering around Tatum salt dome, Lamar County, Miss. Knowledge is based on study of sonic or electrical logs of 230 wells, many of which are 12,000 feet deep and penetrate formations that range from Jurassic ( ?) to Holocene. Thicknesses of rock units are shown on three isopach maps ; four structure maps show tops of major rock groupings. Eight shallow-piercement domes are in the area. Miocene beds covering Tatum dome have been arched 500 feet since their deposition; Citronelle sand and gravel deposits have been removed by late Pleistocene and Holocene erosion.

Ellison, B. E., and Lang, J. W., 1966, Emergency water-supply sources in the Jackson area, Mississippi : Mississippi Board Water Commissioners openfile report. Hydrologic atlas with data tables and short text on one side of single sheet; supply wells and storage sites plotted on the latest highway and street network on the other side. Primarily for use by city and civil defense officials in locating and utilizing safe water for drinking and other critical needs during unforeseen emergency periods.

Fenneman, N. M., 1938, Physiography of eastern United States: New York and London, McGraw-Hill Book Co., 473 p. This book presents a comprehensive summarization of the physiographic features of Eastern United States, including the Attantic and Gulf Coastal Plains, the Appalachian region, New England, and the interior uplands and lowlands east of the Great Plains.

Fisk, H. N., 1944, Geological investigation of the alluvial valley of the lower Mississippi River: U.S. Dept. Army, Mississippi River Comm., 78 p. A concise presentation of results of an extensive investigation of the geology of the southern part of the river basin with emphasis on the nature and distribution of the Holocene alluvium and on characteristics of the alluvial plain. Records graphically the large amount of detailed information resulting from the study. Contains 80 figures, 11 tables, and 33 plates.

Gaydos, M. W., 1965, Chemical composition of Mississippi surface waters, 194562 : Mississippi Board Water Commissioners Bull. 65-1, 32 p. A tabulation of more than 400 analyses collected at 97 stream sites from 1945 through September 1962 arranged according to river basins. The mean discharge is given for each site at the time the sample was collected. Sampling sites are shown on an index map.

Golden, H. G., 1958, Low-flow characteristics of Pearl River at Jackson, Mississippi : U.S. Geol. Survey open-file report, 9 p. Presents annual minimum daily flow for calendar years 1902-12 and 1928-57 and describes the effect of withdrawals by the city of Jackson and of sewage- and well-water additions to the river. Contains curves of the duration of daily flow and of the magnitude and frequency of annual low flow. 
1959, Temperature observations of Mississippi streams : Mississippi Board Water Commissioner Bull. 59-1, 67 p. A tabulation of temperature measurements obtained by the U.S. Geological Survey during the years 1943 to 1947 and 1954 to 1959 at many gaging stations. Does not include sites where less than eight measurements were made. A continuous record is available from 1954 to 1956 for the Pearl River at Jackson; records for this site and 12 others in the Pearl basin are presented.

Grim, R. E., 1936, The Eocene sediments of Mississippi: Mississippi Geol. Survey Bull. 30, 240 p. Describes character and composition of the sediments, location and source area from which they came, their stratigraphic relations, and conditions under which they were deposited. Several outcrop sections are described. Detailed analyses are given of 66 samples, several of which were taken from the Pearl River basin. Many histograms, 25 figures, and three plates illustrate the report.

Harvey, E. J., 1963, Compilation of aquifer-test data for Mississippi : Mississippi Board Water Commissioner Bull. 63-4, 10 p. Presents the values of transmissibility and storage determined from 43 field pumping tests, and the values of specific capacities and well yields obtained from various groundwater studies in the State. Index maps show locations of the tests and areas of ground-water development according to geologic sources. A table gives the generalized geologic column.

Harvey, E. J., Callahan, J. A., and Wasson, B. E., 1961, Ground-water resources

of Hinds, Madison, and Rankin Counties, Mississippi, part II, basic data : Mississippi Board Water Commissioners Bull. 61-2, 146 p. Contains tables of detailed data on water wells including many well logs and water analyses for each county and a well location map. Very useful for drillers, planners, and developers.

1964, Ground-water resources of Hinds, Madison, and Rankin Counties, Mississippi: Mississippi Board Water Commissioners Bull. 64-1, 38 p. Describes the five aquifers ranging in age from Eocene to Holocene that are available for development of moderate to large water supplies in the threecounty area. Stratigraphy, structure, and water-bearing properties are illustrated and summarized, and water utilization is presented. Hydrologic characteristics are described, including well yields, water levels, quality of water according to formations, and potential for future water-supply developments.

Harvey, E. J., and Grantham, P. E., 1963, Interim report on hydrology of the Cockfield Formation in the vicinity of Jackson, Mississippi: Mississippi Board Water Commissioners Bull. 63-6, 19 p. Summarizes geologic and hydrologic characteristics, including water quality, of the Cockfleld Formation, a major source of water supply in the area around Jackson. Conclusions are drawn about possible effects on the Cockfield of the new Pearl River reservoir northeast of Jackson.

Howe, H. J., 1962, Subsurface geology of St. Helena, Tangipahoa, Washington, and St. Tammany Parishes, Louisiana : Gulf Coast Assoc. Geol. Socs. Trans., v. 12, p. 121-155. Presents information, principally from electric logs and data from files of the Louisiana Geological Survey, on the stratigraphy, structure, and oil and gas production and potential in the area. Contains four geologic sections, seven structural maps, and several tables of oil-field well statistics.

Lang, J. W., 1957, Geology of water resources in Mississippi : First Water and Sewerage Works Operators Short Course, Proc., Mississippi State College Bull. 5741. Reprinted by Mississippi Board Water Commissioners, 1966. 
Presents the application of geology to water supply, describes the outcrops and the areas of development of principal water-bearing units, and tells how the units function as reservoirs. Contains small map, two generalized sections, and table of geologic formations and their water-bearing characteristics.

1961, Ground water in Eocene rocks in the Jackson dome area, Mississippi, in Short papers in the geologic and hydrologic sciences: U.S. Geol. Survey Prof. Paper 424-D, p. D50-D52. A summarization of geologic and hydrologic conditions on and around the large dome. Describes the influence of the structure on thickness, distribution, and water-bearing characteristics of the Sparta Sand and the Cockfield Formation. Contains three figures, one map showing distribution of water-supply sources and two isopach maps showing formation thicknesses.

Lang, J. W., and Boswell, E. H., 1960, Public and industrial water supplies in a part of northern Mississippi : Mississippi Geol. Survey Bull. 90, $104 \mathrm{p}$ A general appraisal of the public and industrial water supplies in a 22-county region. Presents data tables according to counties and gives such pertinent information as water analyses, storage facilities, average daily pumpage, and detailed records of wells. Includes a geologic section. Surface water resources are summarized and water quality and use are described. Contains nine figures, five tables, and one plate.

Lang, J. W., and Newcome, Roy, Jr., 1964, Status of salt-water encroachment in aquifers along the Mississipupi Gulf Coast-1964: Mississippi Board Water Commissioners Bull. 64-5, 17 p. Describes the hydrologic situation, the trends of salt-water encroachment, and the water-quality monitoring system. Presents a compilation of all available chloride determinations according to counties and dates. A map showing the location of data wells and the configuration of the base of fresh water is attached.

Matson, G. C., and Berry, E. W., 1916, The Pliocene Citronelle Formation of the Gulf Coastal Plain and its flora: U.S. Geol. Survey Prof. Paper 98-L, p. 167-208. Summarizes earlier investigations and nomenclature difficulties and describes stratigraphic relations, lithology, structure, and thickness of the Citronelle. Floras of the formation are described. Report is well illustrated with drawings, photographs, and plates of plant fossils.

McGlothlin, Tom, 1944, General geology of Mississippi : Am. Assoc. Petroleum Geologists Bull., v. 28, no. 1, p. 29-62. Briefiy describes the stratigraphy of formations ranging in age from late Paleozoic to Holocene. Three maps and 13 sections are presented.

McGuinness, C. L., 1963, The role of ground water in the national water situation : U.S. Geol. Survey Water-Supply Paper 1800, p. 444-457. Briefiy describes the ground-water situation in Mississippi according to large areas. Points out problems, prospects, and needs for scientific investigations to offset informational deficiencies.

Monroe, W. H., 1954, Geology of the Jackson area, Mississippi. U.S. Geol. Survey Bull. 986, 133 p. Detailed report of the geology. Includes topographic base maps with superimposed geologic outcrop pattern. Several outcrop sections and cuttings from six deep oil and gas wells are described in detail. Contains a discussion on the economic geology.

Moore, W. H., and others, 1965, Hinds County geology and nineral resources: Mississippi Geol. Survey Bull. 105, 244 p. A comprehensive report based on a detailed study of the geology and mineral resources of Hinds County. 
Contains 50 figures, 15 plates, and 16 tables of data. Descriptions are given of cuttings and cores from 63 test holes drilled in conjunction with the study.

Murray, G. E., 1947, Cenozoic deposits of central Gulf Coastal Plain: Am. Assoc. Petroleum Geologists Bull., v. 31, no. 10, p. 1825-1850. Detailed paper summarizing the Cenozoic stratigraphy of Mississippi and areas immediately adjacent thereto and describing both surface and subsurface units. Gives general lithologic character and thickness of units and application of units to geologic mapping. Contains nine maps and an electrical-log section.

Neely, B. L., Jr., 1964, Floods of 1962 in Mississippi : Mississippi Board Water Commissioners Bull. 64-6, $97 \mathrm{p}$. Contains data for four noteworthy floods that occurred during the 1962 water year (October 1961-September 1962). Describes the precipitation patterns, floods, river proflles, and related matters. Contains ten tables of data and 27 flgures, including isohyetal maps, graphs of stages and discharges, and several photographs.

Newcome, Roy, Jr., 1965, Configuration of the base of the fresh-ground-water section in Mississippi : Mississippi Board Water Commissioners Water Resources Map 65-1. State map shows contours drawn on the base of the fresh-water section (dissolved-solids content less than $1,000 \mathrm{mg} / 1$ ). Scale, 18 miles per inch; contour interval, 500 feet. Data are from electrical logs of oil company borings and from water-well records.

1967a, Development of ground-water supplies at Mississippi Test Facility, Hancock County, Mississippi : U.S. Geol. Survey Water-Supply Paper 1839H, 28 p. Describes test drilling and development of deep aquifers previously untapped in the area. Provides details of well testing and aquifer characteristics, including transmissibility and specific-capacity values, and discusses well efficiency. Contains 11 flgures, three data tables, and a plate showing well locations and geohydrologic sections.

1967b, Ground-water resources of the Pascagoula River basin, Mississippi and Alabama: U.S. Geol. Survey Water-Supply Paper 1839-K, 36 p. Summarizes the major aspects of ground-water occurrence and development and the interrelation of these aspects with the geology of the river basin. Contains four tables and 12 illustrations, including two electric-log cross sections and a base-of-fresh-water map.

Robinson, W. H., and Skelton, John, 1960, Minimum flows at stream-gaging stations in Mississippi: Mississippi Board Water Commissioners Bull. 60-1, $91 \mathrm{p}$. Presents all available basic data to date on low flows at stream-gaging stations in the State. Contains an index map showing station locations and a table giving the average minimum flows for selected stations according to river basins.

Rollo, J. R., 1960, Ground water in Louisiana : Louisiana Geol. Survey and Dept. Public Works Water Resources Bull. 1, 84 p. Summarizes the general availability of ground water in the State. Aimed at aiding those organizations responsible for planning and development of water supplies, particularly industries making preliminary site studies, water-well drillers, oil companies, and State agencies. Report contains 16 flgures, four plates, one of which is a fence diagram showing subsurface geology of the State, and 10 tables, seven of which are chemical analyses of water samples from the different geologic units.

Shell, J. D., 1964, Flood on Pearl River at Jackson, Mississippi, in 1961: U.S. Geol. Survey Hydrol. Inv. Atlas HA-127. Shows on a photomosaic base the area inundated by the 1961 flood. Describes and shows in six figures flood 
height, frequency and recurrence intervals, and flood profiles. A table gives dates and data for other noteworthy fioods since 1880 .

Skelton, John, 1961, Low-flow measurements at selected sites on streams in Mississippi : Mississippi Board Water Commissioners Bull. 61-1, 135 p. Presents results of low-flow measurements made by the U.S. Geological Survey at sites other than stream-gaging stations. Conltains seven maps showing locations of sites according to river basins and a table giving selected sites with average minimum flow of zero and the years the flow was observed.

Stephenson, L. W., Logan, W. N., and Waring, G. A., 1928, Ground-water resources of Mississippi, with discussions of the chemical character of the waters, by C. S. Howard: U.S. Geol. Survey Water-Supply Paper 576, 515 p. First overall comprehensive report on ground water in Mississippi ; still a valuable reference. Describes the physiography, general geology, surface and ground water, and the general chemical characteristics of the waters. Ground-water resources are described according to counties; well logs, well records, and water analyses are presented. Contains three figures, 12 plates, including a geologic map of Mississippi, and a table insert showing the generalized section of geologic formations and their water-bearing characteristics.

Taylor, R. E., 1966, Ground water in the Tatum Dome area, Lamar County, Mississippi, in Mississippi Water Resources Conference, Proc., 1966: Water Research Inst., Mississippi State Univ., p. 141-148. Geologic and hydrologic conditions of a 4-square-mile area centering on the salt dome are described. Six major acquifer systems are present; three have been pierced by the salt stock of the dome. The report discusses ground-water movement, acquifer head, and water quality.

Taylor, R. E., Humphreys, C. P., Jr., and Shattles, D. E., 1968, Water for industrial development in Covington, Jefferson Davis, Lawrence, Marion, and Walthall Counties, Mississippi: Jackson, Mississippi Research and Devel. Center, $114 \mathrm{p}$. An evaluation is made of the water resources of this six-county area in south-central Mississippi. Area uses $9.7 \mathrm{mgd}$, mostly ground water, but more than seven times this daily rate has been allocated from Pearl River alone for a new industry. Even during a 10-year-long drought, natural flow of the Pearl persists, and it increases from $160 \mathrm{mgd}$ at northern Lawrence County line to $\mathbf{7 0 0} \mathrm{mgd}$ at southern Marion County line. Water from streams and aquifers is of good quality. Some acquifers are untapped. Large diameter wells in some areas could produce as much as 2,500 gpm each.

U.S. Public Health Service, 1962, Drinking water standards, revised in 1962: U.S. Public Health Service Pub. 956, 61 p. Applies to drinking water used on interstate common carriers and on others subject to Federal quarantine regulations; often used as a standard for evaluating the suitability of all water supplies. Recommends that water contain less than $500 \mathrm{mg} / \mathrm{l}$ dissolved solids but implies that where water of such quality is not available more highly mineralized water may be used.

Wasson, B. E., 1971, Water resources of the Big Black River basin: U.S. Geol. Survey Water-Supply Paper 1899-F (in press). Summarizes the basin's geohydrologic conditions, including ground water-surface water relationships. Contains 13 illustrations and four tables, including chemical analyses, duration flows of streams, and acquifer characteristics.

1963, Water resources of Attala County, Mississippi, in Attala County mineral resources: Mississippi Geol. Survey Bull. 99, p. 139-191. Describes the occurrence, quantity, availability, and quality of the water resources in the county. Illustrated by 12 figures and a plate (geologic section). Seven 


\section{M44 CONTRIBUTIONS TO THE HYDROLOGY OF THE UNITED STATES}

tables are presented, two of which are chemical analyses of samples from wells and streams and one of which gives detailed records of selected water wells.

Wilson, K. V., 1964, Floods of 1961 in Mississippi : Mississippi Board Water Commissioners Bull. 64-4, 93 p. Contains rainfall and discharge data for five noteworthy fioods that occurred during 1961. Describes rainfall patterns, fiooding and fiood damage, and river profiles. Illustrated by 37 figures, including isohyetal maps, aerial photographs, fiood profiles, and graphs of stages and discharges. Basic data are presented in eight tables.

Wilson, K. V., and Ellison, B. E., Jr., 1968, Floods of the 1965 water year in Mississippi : Mississippi State Highway Dept., and Mississippi Board Water Commissioners Bull. 68-2, 20 p. Floods caused by Hurricane Hilda, Oct. 1964, were the greatest of record in southern Mississippi. As much as 121/2 inches of rain fell in the McComb-Brookhaven area in 24 hours; 10 inches fell over an area of 1,300 square miles, and 8 inches over an area of 4,000 square miles. Report contains data for four floods: Oct. 3-5, 1964 ; Nov. 28, 1964 ; Dec. 10-12, 1964; and Feb. 12-19, 1965. Data include five figures and a table giving flood stages and discharges for the Hurricane Hilda events.

Wilson, K. V. and Trotter, I. L., 1961, Floods in Mississippi, magnitude and frequency: Jackson, Mississippi State Highway Dept., Traffic Plan Div., 326 p. A comprehensive compilation of data tables with 22 figures. Evaluates the flood potential anywhere in Mississippi as it relates to design of structures on the fiood plains of streams.

Winner, M. D., Jr., 1963, The Florida Parishes-An area of large, undeveloped ground-water potential in southeastern Louisiana: Baton Rouge, Louisiana Dept. Public Works, 50 p. Summarizes ground-water data collected since 1938 but is based largely upon fieldwork done in 1960 and 1961. Discusses the geology and the general occurrence, availability, potential development, and water quality of ground water; describes ground-water withdrawals and their effects. Contains three plates, five figures, and five data tables. 
Contributions to the Hydrology of the United States,

\section{9}

GEOLOGICAL SURVEY WATER-SUPPLY PAPER 1899

This volume was printed as separate chapters $A-M$

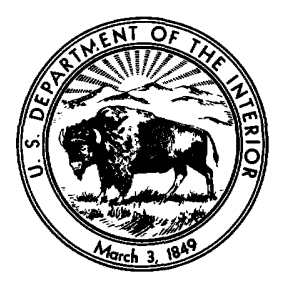


UNITED STATES DEPARTMENT OF THE INTERIOR

ROGERS C. B. MORTON, Secretary

GEOLOGICAL SURVEY

V. E. McKelvey, Director 


\section{CONTENTS}

[Letters designate the separately published chapters]

(A) Ground-water resources of the Clatsop Plains sand-dune area, Clatsop County, Oregon, by F. J. Frank.

(B) Water resources of Lee County, Mississippi, by B. E. Wasson and F. H. Thomson.

(C) Sediment transport by streams in the Palouse River basin, Washington and Idaho, by P. R. Boucher.

(D) Water resources of north-central Oahu, Hawaii, by J. C. Rosenau, E. R. Lubke, and R. H. Nakahara.

(E) Ground water for irrigation in the Booten-Belgrade area, west-central Minnesota, by Wayne A. Van Voast.

(F) Water resources of the Big Black River basin, Mississippi, by B. E. Wasson.

(G) Measurement of mixing characteristics of the Missouri River between Sioux City, Iowa, and Plattsmouth, Nebraska, by Nobuhiro Yotsukura, Hugo B. Fischer, and William W. Sayre.

(H) Geohydrology of Hualapai and Sacramento Valleys, Mohave County, Arizona, by J. B. Gillespee and C. B. Bentley.

(I) Streamflow from the United States into the Atlantic Ocean during 1931-60, by Conrad D. Bue.

(J) Ground water for irrigation near Lake Emily, Pope County, west-central Minnesota, by Wayne A. Van Voast.

(K) A glossary of karst terminology, compiled by Watson H. Monroe.

(L) A preliminary evaluation of bank storage associated with Libby Reservoir in Northwestern Montana, by Donald L. Coffin.

(M) Geohydrologic summary of the Pearl River basin, Mississippi and Louisiana, by Joseph W. Lang. 
